\title{
Çanakkale Cephesi Deniz Savaşlarında 18 Mart Kahramanı Cevat (Çobanlı) Paşa
}

\author{
Nurdan BAŞ
}

$\ddot{O} z$

Çanakkale Deniz Savaşlarında görev alan Cevat (Çobanlı) Paşa'nın tarihe 18 Mart kahramanı olarak yazılması O'nun askeri ve stratejik başarısıdır. Bu çalışmada Çanakkale cephesinde özellikle deniz savaşlarında görev alan Cevat Paşa'nın faaliyetlerine yer verilmiştir. Araştırmada, Çanakkale'de I.Dünya Savaşında Osmanlı ordusunun verdiği başarllı mücadelede Cevat Paşa'nın rolü ortaya konulmaya çalışılmıştır. Ayrıca; Cevat Paşa'nın bu cephedeki faaliyetleri ve bu dönemle ilgili bazı anılarına yer verilerek, Çanakkale Deniz savaşları Cevat Paşa boyutundan anlatılmıştır

Anahtar Kelimeler: Cevat Paşa, Çanakkale, taarruz, savunma, deniz

\section{Cevat (Çobanlı) Pasha the Hero of 18 March in Naval Wars of Çanakkale Front}

\begin{abstract}
Cevat (Çobanll) Pasha was labelled as 18 March hero thanks to his military and strategic achievements in his duties during Çanakkale Naval Warfare. This study is about the activities of Cevat Pasha in the Çanakkale Front. The study aims to identify the role of Cevat Pasha in the success of the Ottoman Army in Çanakkale during the World War I. In addition, the study elaborates on the Çanakkale Naval Warfare from the perspective of Cevat Pasha by putting his activities and memories to the centre.
\end{abstract}

Keywords: Cevat Pasha, Çanakkale, attack, defense, sea 


\section{Giriş}

Genel hatlarıyla baktığımızda Birinci Dünya Savaşı sadece Osmanlı Devleti için değil, dünya tarihi açısından da önemli gelişmelerin yaşandığı ve ileriye dönük de yaşanacağı siyasi, sosyal, kültürel ve ekonomik çıkarımların olduğu ve sonrasında da olacağı bir tarihin dönüm noktasıdır. Hiç kuşkusuz Çanakkale Cephesi Birinci Dünya Savaşının başlangıç hedef ve sonuçlarını alt üst etmiştir. Avrupa da büyük devletlerinin oluşturduğu siyasî gruplaşmaların ve bu büyük devletlerin ekonomik çıkarları karşısında Osmanlı Devleti'nin durumu son derece kritik ve karanlıktı. Buna rağmen bu cephe ile stratejik açılımlar tamamen değişecektir. Çanakkale Cephesi sadece bir savaşın uzaması değil, yeni bir dönemin de başlangıcıydı. İşte bu başlangıçta öne çıkan isimlerin içerisinde Cevat (Çobanlı) Paşa'da yer almıştır. ${ }^{1}$

Çanakkale Savaşları dünya tarihinin kaydettiği en önemli olaylardan biri olmuştur. Düşman devletlerinin sadece Anadolu toprakları için değil özellikle de Boğazlar üzerindeki istekleri belli ve çok yönlü olmuştur. Osmanlı Devleti Birinci Dünya savaşı öncesinde birbirini izleyen harpler ve ayaklanmalar nedeniyle de eski gücünü kaybetmişti. Bu çerçeve içerisinde yıkılmaya başlamış bir Osmanlı Devleti savaş öncesinde tarafını belirlemek durumunda kalmıştır ve Almanya'nın yanında bu harbe girmiştir.

"Almanlar, Baltık-Bosfor-Basra ekseninde kuracakları jeopolitik bir kuşakla Akdeniz ve Hint Okyanusu'na uzamak istiyorlardl. Bu proje Balkanlar üzerinden ve büyük kısmıyla Osmanlı Devleti'nin sırtından gerçekleştirilecekti. Rusların, açık denizlere ve sıcak iklimlere çıkma politikalarının hedefi de aynı coğrafya idi. Londra otoritelerine göre, Osmanlı Devleti yaşamını tamamlamış, mirasını paylaşmak zamanı gelmişti. Fransızlar da, benzer koşullar dolayısıyla aynı politikayı izliyorlardı. Üçlü anlaşmanın temelinde yatan müşterek hirs buydu. Bu nedenle her iki taraf da Osmanlı Devleti'yle anlaşmaya yanaşmıyordu. Avusturya-Macaristan Devleti, Veliahtları Arşidük Fransuva Ferdinand ve eşinin Saraybosna'da öldürülmesi nedeniyle Strbistan'a harp ilân edip, Birinci Dünya Harbini başlattı. Bir süre sonra da Almanya, Rusya ve Fransa'ya karşı harbe girdi.”

1 Cevat (Çobanlı) Paşa, Osmanlı Devleti’nin 20. yüzyıl başlarındaki çöküş döneminde ve Cumhuriyetin ilk yıllarında meydana gelen siyasi olayların içinde fiili olarak bulunmuştur. Balkan Savaşları, I. Dünya Savaşı, Milli Mücadele ve Cumhuriyet'in ilanına gidilen süreçte yaşanan siyasi, sosyal, ekonomik ve kültürel gelişmelerde; TBMM'nin açılması, Türkiye Cumhuriyeti’nin kurulması ve laikleşme sürecinde yapılan inkılap hareketleri içerisinde yer almıştır. Cevat (Çobanlı) Paşa 1870'te başlayıp 1938’e kadar süren yaşamında, eğitim döneminden itibaren bir asker olarak yetişmiş, Osmanlı sarayında yaverlik yapmış, 1911-1912 Trablusgarp Savaşı; 1912-1913 Balkan Savaşı; 1914-1918 Birinci Dünya Savaşı; 1919-1922 İstiklal Savaşında bulunmuş, Çanakkale Savaşlarında, üstün zeka ve askeri stratejisiyle önemli kazanımlar ortaya çıkarmıştır. Nurdan Baş, Orgeneral Cevat Çobanlı'nın Biyografisi, (Yayınlanmamış Yüksek Lisans Tezi), Ankara,2013

2 Nusret Baycan, "Orgeneral Cevat Çobanlı”, Atatürk Araştırma Merkezi Dergisi, Sayı 20, Cilt: VII, Ankara,1991 ,s.375; Cevat (Çobanlı) Paşa ve Çanakkale Deniz Savaşlarıyla ilgili bakılabilecek ek bir çalışma olarak bknz. Recep Dündar, Birinci Dünya Harbi Çanakkale Deniz Muharebeleri ve Müstahkem Mevki Kumandanı Cevad (Çobanlı) Paşa'nın Faaliyetleri, (Yayınlanmamış Yüksek Lisan Tezi), Malatya, 1992 
Almanya açısından Çanakkale Cephesi apayrı bir konudur. Tıpkı Osmanlı Devleti ve Almanya'nın aynı tarafta yer alması gibi. Bu konuyla alakalı savaşın gidişatıyla ilgili çok farklı bir profille karşılaşırız. İsmet Görgülü’nün “Çanakkale’de Almanların Niyeti” adlı çalışmasında önemli ayrıntıları ve konu başlıklarını görürüz. Sonuç kısmında şu cümle dikkat çekicidir: " Çanakkale muharebelerinde Almanlar kendi çıkarlarına göre harekatı yönlendirmiş ve yönetmiştir. Bunu yaparken müttefikleri olan Türkleri dikkate almamışlar, sadece niyetleri doğrultusunda kullanmışlardır...” ${ }^{3}$ Tüm çıkarcı planlamalara rağmen Çanakkale Savaşı Türk komutanların stratejik başarısı ve askerin sabır, irade ve inancıyla lehte sonuçlanmıștır.

Çanakkale Savaşları İngiltere'nin öncülüğünde Fransızların ve çok sınırlı olarak da Rusya ve Avusturya'nın katılımı ile gerçekleşmiştir. Cephenin açılma önerisi Rusya'dan gelmiş ve planlamayı da Churchill yapmıştır. Tüm bu geniş katılıma, çok kısa sürede Türk ordusunun kendi güçleri karşısında tutunamayacağını planlamış olmalarına rağmen beklentiler Çanakkale'nin derin sularına gömülmüştür. ${ }^{4} \mathrm{O}$ güne kadar hiçbir yenilgi almamış ve tarihin en büyük armadası olarak değerlendirilen Birleşik Filo, Çanakkale Boğaz'ında hiç beklemedikleri mağlubiyeti tatmış olacaklardı.

Elbette Osmanlı Devleti'nin savaşa girmesi yararına idi. Osmanlı Devleti bu savaș esnasında yalnız kalmak istemiyordu. Hatta 27 Temmuz 1914'te Almanya ile bir ittifak yapılması için -görüşmelere- ${ }^{5}$ bile başlanmıştı. ${ }^{6}$

"Osmanlı Devleti, Birinci Dünya Savaşı’na girmeden evvel varlığını denge politikası izleyerek devam ettirmeye çalışılyordu. Ne var ki bu denge politikası bir süre başarılı olmuş ancak 19.yüzyllın sonlarında uygulanmaya çalışıllan politika yeterince sonuç verememiştir. 20. yüzyıl başlarında ise gerek iç politikada ve gerekse dış politikada yaşanan sorunlar nedeniyle Osmanlı Devleti oldukça yıpranmışve varlı̆̆ını devam ettiremeyecek bir devlet konumuna düşmüş̦tür. Kaldı ki 1900'lü yılların başlarında meydana gelen olaylar (Trablusgarp Savaşı, Balkan Savaşları) Osmanlı Devleti’ni siyasal arenada varllğını devam ettirebilmesi için güçlü bir müttefik bulmaya zorlamaktaydı. İște bu sebeple savaş öncesi ittifak arayışlarına başlayan Osmanlı Devleti, çeşitli girişimlerden sonra Almanya ile işbirliği yapacaktır. Gerek siyasal, gerekse askeri ve ekonomik alanda yapılan bu işbirliği savaș süresince devam edecek ve ordunun sslahı konusunda Almanya'dan büyük ölçüde faydalanilacakttr?"

3 İsmet Görgülü, "Çanakkale'de Almanların Niyeti”, Çanakkale Araştırmaları Türk Yılllğı Dergisi, S.1, Çanakkale, 2003, s.178

4 Cemalettin Taşkıran, "18 Mart Çanakkale Deniz Savaş̧", ATAM, C.25, S.73,Ankara, 2009, s.28

5 Bu görüşmeler, 2 Ağustos 1914’te Sadrazam Halim Paşa ile Almanya’nın İstanbul büyükelçisi Baron von Wangenheim arasında, Osmanlı-Almanya Anlaşması imzalandı. Rıfat Uçarol, Siyasi Tarih, İstanbul, 2000, s.466

6 Yücel Özkaya, "1914-1918 Yılları Arasında Birinci Dünya Savaşı”, Milli Mücadele Tarihi, c. 1, Ankara, 2005, s. 7

7 Ali Kaşıyuğun, “ Osmanlı Devleti'nin Birinci Dünya Savaşına Girmeden Önceki İttifak Arayışları”, History Studies Dergisi, 2009, S.1, s. 319 
Osmanlı Devleti açısından Almanya ile savaşa girmek çıkış noktalarından bir tanesiydi. Çünkü düşman kuvvetler tarafından Osmanlı Devleti toprakları üzerinde büyük planlar uygulanmaya başlamıștı. Bu planlar Birinci Dünya Savaşının çok öncesinde tasarlanmıştı. Ancak büyük devletlerin istekleri tam anlamıyla çözülememişti. Onlar tarafından çözüme giden yollardan bir tanesi Çanakkale'ydi. Anadolu toprakları üzerinde yapılan planların uygulanması için "hasta adam” gözüyle bakılan Osmanlı Devleti’nin artık kesin olarak varlığına son verilmeliydi. Çanakkale Savaşlarına dek Osmanlı Devleti üzerinde düşünülen kesin sonuç askeri ve siyasi pek çok denemede istekleri doğrultusunda tam anlamıyla başarıya ulaşamamıştı.

"İște İngiliz, Fransız, Rus ve İtalyanların bütün bu başarısız denemeleri, Birinci Dünya Savaşı başlarında hepsinin oluşturdukları pakt içinde Ingiliz ve Fransızlar ve beraberlerinde getirdikleri Avustralyalı ve Yeni Zelandalılar tarafindan son bir defa daha tekrarlanmıştır. Bu sefer müteferrik değil, müşsterek çıkarlarla hareket edilmiştir. Amaç sadece Boğazları ele geçirerek İstanbul'a sahip olmak değil aynı zamanda Rusya'nın yükünü hafifleterek doğrudan temasa geçmek, Balkanlar'da İtilâf güçlerine katılmamış olan mütereddit devletleri halka içine almak; buradan Osmanlı ordusuyla Alman ordusunun muhtemel temas ve sevkiyatını kesmek; Kafkaslar ve Doğu Anadolu'da Rusları rahatlatmak, Arap vilâyet veya eyaletlerinde Osmanlılara karşı girişilen harekâtta İngiliz, Fransız ve İtalyanlara kolaylık sağlamak ve nihayet Almanları da belirli ölçüde meşgul ederek Avrupa savaşlarında üstünlük elde etmektir. Bunların dışında, Osmanlı Devletinin birçokyerini de İtilâf Devletleriyle birlikte kendilerine muhtariyet veya istiklâl vaad edilen Araplar, Rumlar ve Ermeniler arasinda paylaşmaktan ibarettir.Bütün bu hesaplar, masa başlarında yapıldı̆̆ı, bazı gerçekler gözden kaçırıldı̆̆ı, mahallerindeki incelik ve özellikler düşünülmediği, Avrupalı'nın mantı̆̆ında ölümcül bir hastalığa yakalanmış olan hasta adamın artık cevvaliyetini yitirdiği zehabılla karşı koyacak güce sahip olmadı̆̆ ve özellikle de, özüne, canına kastedilip boğazına sarılınca Türklerin neler yapabileceği unutulduğu için akamete uğramıştır. Öncesinde, Çanakkale Savaşlarıla tüm bu düşüncelerin kesin bir neticeyle hayata geçeceğinden emin bir itilaf gücü oluşturmuşlardl. ${ }^{8}$ "

Çanakkale Boğazı'na saldırı planı Amiral Carden tarafından hazırlandı. Plana göre önce Boğaz’ın girişini savunan dış bataryalar uzun mesafelerden bir ateşle tahrip edilecekti. Dış bataryaların ikisi Boğaz'ın Anadolu yakasında bulunan Orhaniye ile Kumkale'de, diğer ikisi de Rumeli yakasındaki Ertuğrul ile Seddülbahir'de bulunuyordu. Boğaz’ın bu tabyalar arasındaki genişliği 4 km kadardı. Bundan sonra Boğaz’a girilerek Anadolu yakasında Kepez ve Rumeli'de Kilitbahir'e kadar olan ve merkez

8 Azmi Süslü, “Çanakkale Savaşları ve Önemi”, Atatürk Araştırma Merkezi Dergisi, S. 20, c. VII, Ankara, 1991 
savunma sistemi denilen tahkimat ve buralardaki bataryalar tahrip edilecekti. Bu da tamamlanınca Çanakkale ile Nara Burnu arasındaki savunma sisteminin son kısmı ateş altına alınacak ve Marmara'ya girilerek İstanbul'a yönelecekti. Bu bombardıman aşamalarının her birinde savaş gemileri yol almaya başlamadan önce torpil alanları temizlenmiş olacaktı. Planın başarılı bir şekilde uygulanabilmesi havaların iyi gitmesine; yeterli cephane sağlanmasına ve Türklerin savunmada göstereceği zafiyet ve yılgınlığa bağlanmıştı. ${ }^{9}$ Türk tarafının herhangi bir başarısının söz konusu dahi olabileceği bu planlar dahilinde tutulmuyordu. Yapılan saldırı planında unutulan tek başlık geri çekile bilme ihtimaliydi. 18 Mart, bu anlamda, İtilaf devletlerinin beklemedikleri karşı saldırıyla önemli kayıplar yaşamasına yol açmıştır. ${ }^{10}$ Çanakkale cephesindeki bu ilk önemli adım Türklerin başarısıyla neticelenmiştir. Bu başarı savaşın gelecek olan diğer zor bölümü için de büyük bir umut kaynağı olmuştur.

O günlerde Türk Ordusu, dört ordu müfettişliği emrinde on üç kolordu halinde teşkilatlanmış 38 piyade 4 süvari tümeninden ibaretti. Ateş gücü zayıftı, fenni birliklerle geri teşkiller, özellikle ulaştırma birlikleri yok denecek kadar azdı. Noksanlarının giderilmesi ve Türk ordusunun kısa sürede savaşa hazırlanması için Türk ve Alman subayları el ele vererek büyük bir gayretle çalışmaya başladılar. ${ }^{11} \mathrm{Bu}$ çalışmaların içinde küçük yaşlardan beri aldığı eğitimle tüm bilgi ve donanımını askerlik görevine aktaran Cevat Paşa'da yer alacaktır. O'nu Çanakkale Boğazı'ndan düşman gemilerini İstanbul'a sokmayan, geri çeviren komutan olarak göreceğiz. Başlangıçta İtilaf güçlerine karşı el ele veren bu iki devletin mutlak galibiyetini Türk komutanlarının ve Mehmetçiğin gayretleriyle kazanıldığını söylemek yanlış olmayacaktır.

Cevat (Çobanlı) Paşa'nın Birinci Dünya Harbi'nde adını "18 Mart Kahramanı" olarak tarihe geçiren görevi ise Çanakkale Cephesindeki üstün başarısı olmuştur. O’nun Çanakkale Deniz Savaşlarındaki stratejik savaş tekniği ile yakaladığı başarı düşman güçlerini hayal kırıklığına uğratmış ve onların mevcut planlarını tersine çevirmiştir. Çanakkale'yi geçerek Osmanlı Devleti'ne artık son hamleyi vuracaklarını düşünen İtilaf Devletleri, 18 Mart'ta geri çekilebileceklerini planlarına hiçbir şekilde dâhil etmemişlerdi.

\section{18 Mart Kahramanı Cevat Paşa}

Çanakkale Cephesi “Deniz Harekâtı” ve burada yapılan savaş Osmanlı Devleti’nin Birinci Dünya Harbinde ileri seviyedeki başarısını oluşturmaktadır. Böylece harbin

9 Taşkıran, s. 29-30; A. Thomazi, Çanakkale Deniz Savaşı, Ankara, 1997, s. 17

10 İtilaf Devletlerinde 18 Mart'ta Boğaz’ı geçmek için 12 büyük zırhlı gemi ile savaşa katılmıștı. Bunlardan 3'ü batmış, 4 'ü de savaş dışı kalmıştı. İngiliz ve Fransızların 44 top ve 800 de insan kayıpları vardı. Diğer gemiler de çok az çok isabet almışlardı. Taşkıran, s. 36; Birinci Dünya Savaşında Çanakkale Cephesi, (Yay. Krl. Bşkn. Kamil Başoğlu), V.Cilt, 1.Kitap, Ankara 2012, s. 47

11 İsmet Görgülü, On Ylllık Harbin Kadrosu 1912-1922, Ankara,1993, s. 48 
seyri değişmiş, halkın ve askerin umudu artmıștır. Cevat Paşa'nın buradaki konumu ve uyguladığı askeri başarı genel anlamda Türk Ordusunun güçlü stratejilere sahip olduğunun en güzel göstergesi olmuştur. Burada görev alan diğer komutanlarla beraber Çanakkale Deniz Savaşları ve genel olarak Çanakkale Cephesi, Osmanlı Devleti'nin en son kazandığı askeri başarısı olacaktır. Bu cephe; kazanım, etki alanı ve kayıplarıyla dünya tarihinde de yer etmiştir. Yeri ve önemi tek taraflı düşünülmeyecek kadar uluslar arası bir boyuttadır. Günümüzde halen daha sadece Türk tarafından hatırlanmaması da bunun bir göstergesini oluşturmaktadır.

10 Ağustos 1914'te Çanakkale Müstahkem Mevki Komutanlığı'na atanan Cevat Paşa ${ }^{12}$ birliklerini (özellikle müstahkem mevki topçusunu) ve 9 ncu Tümen'i muharebeye hazırlamış, Başkomutanlığa verdiği bir raporla da yaptığı ve yapacağı işleri bildirmişti. Bu raporda, denizden yapılacak bir taarruzda kesin savunmanın Boğaz'ın iç kısmında yapılması üzerinde duruyor, Boğaz'ın giriş kısmının her zaman kolayca düşürülebileceğini savunuyor ve Erenköy koyunun düşmanın sığınmasına engel olacak şekilde mayınlanmasını öneriyordu. ${ }^{13}$

13 Ağustos 1914 tarihinde Çanakkale Müstahkem Mevki Komutalığı tarafından verilen emirle Boğaz girişinin ilerisinde İngiliz gemilerinin görüldüğü her türlü teşebbüse karşı birliklerin daima hazır olması ve sahilde meydana gelebilecek bir teşebbüse ateşle karşılık verilmesi, ağır topçu birliklerinin bölgenin önemi derecesinde hazırlık derecesini arttırması, mayın müfrezesinin istenildiği zamanda göreve başlayacak şekilde bütün önlemleri alarak işaret kulesini daima gözetleyeceği torpidoların geceleyin Boğazın güvenliğini sağlayacak şekilde Boğaz girişi ilerisinde keşfe devam edeceği belirtilmiştir. Torpidoların gözetleme konusunda dikkatli davranmaları hususuna çok önem verilmesine rağmen bu konuda bazı aksaklıklar görülmüş bu durum Müstahkem Mevki komutanı tarafından 13 Ağustosta verilen emirle dikkatsizliği görülen kişilerin en ağır şekilde cezalandırılacağı bildirilmiştir. ${ }^{14} \mathrm{Hiçbir}$ şekilde askeri hataların affı olmaması ve her anın her adımın ivedilikle yapılabilmesi gerekiyordu. Uygulanacak planlar büyük, bunu sağlayacak askeri teçhizat yetersiz ve karşıdaki düşman her açıdan donanımlıydı. Cevat Paşa, bu disiplin içerisinde tedbirlerini almıştı.

Boğaz girişinin biraz ilerisinde keşifte bulunmak üzere tayyare uçurulmak istenmiş ise de tayyare subayı tayyarenin bir gün açıta kalması nedeniyle pervane ve motorda arıza bulunduğundan uçmanın mümkün olmayacağını bildirmiştir. Bunun

12 Başkomutan vekili Enver Paşa, Müstahkem Mevki komutanı Emin Paşa'nın bu konuda yetersiz olduğu düşüncesiyle emin Paşa'yı görevden alarak yerine 9. Tümen Komutanı Kurmay Albay Cevat Paşa’yı atamıștır, Cevat Paşa, 10 ağustos tarihinde göreve başlamıștır; Birinci Dünya Savaşında Çanakkale Cephesi, (Yay. Krl. Bşkn. Kamil Başoğlu), V.Cilt. 1.Kitap, Ankara 2012, s. 74.

13 Baycan, s. 376; Ayrıca bilgi için bkz. Çanakkale Savaşları Özel Sayı ATAM Dergisi, cilt: XXV, sayı:73, Mart, Ankara 2009.

14 Birinci Dünya Savaşında..., s. 75. 
üzerine Müstahkem Mevki Komutanı Cevat Paşa, durumu Başkomutanlığa şu ifadelerle bildirmiştir:

"Daha önce bilgi alınamaması nedeniyle gelen tayyare için sahilde gerekli hangar hazırlanmadığından ve tayyarenin dün geceyi açıkta geçirmesi nedeniyle, tayyareci subay, pervane ve motorun bozukluğundan şikâyet ederek uçmaktan kaçınıyor. Zaten gelen kişilerden biri daha önce burada bir ay kaldiğı halde bir defa bile uçamamıştır. Buraya iş görecek bir tayyare ile bir tayyarecinin gönderilmesi şu anda burada bulunan tayyarenin sökülüp vapurla İstanbul'a nakline izin verilmesi arz edilir."15

Savaş başlamadan önce, Osmanlı'nın Müstahkem Mevki Komutanlığı'na bağlı olarak sefer kuruluşunda kağıt üzerinde de olsa, hava birlikleri vardı. Bunlar daha sonra işlerliğe kavuşmuş ve bölük düzeyine kadar yükseltilmişlerdir. Çanakkale'de Osmanlı'nın 1. Bölük, 6. Bölük ve 3. Deniz Tayyare Bölüğü olmak üzere toplam üç tane birliği vardı. ${ }^{16}$ Ancak hava birliklerinin büyük eksiklikleri savaş için çok da fazla tesirli olamamıştır. O yüzden pek çoğu sadece kağıt üzerinde kalmıştır. Deniz savaşında en önemli askeri teçhizat az sayıda da olsa denize döşenecek mayınlardı. Zaten Çanakkale Deniz Savaşının kazanımını özel kılan da buydu. Az olması bir yana orada uygulanan tedbir ve strateji bu savaşın başarısına giden yoldu.

Başkomutanlık tarafından 22 Ekim 1914’te Çanakkale Müstahkem Mevki Komutanlığına gönderilen bir direktifte Başkomutanlık Delegesi Amiral Metren başkanlığında, Albay Cevat, Yarbay Wossidlo ve Müstahkem Mevki Kurmay başkanından oluşan bir komisyon kurulduğu bildirilmiştir. Bu komisyona her türlü taarruza karşı mevcut vasıtalarla Boğaz’nn ne şekilde savunula bileceği ve muhtelif bataryalarla diğer savunma vasıtalarının ne şekilde hareket edeceklerine dair bir plan hazırlanması emredilmiştir. ${ }^{17}$ Cevat Paşa'nın 18 Mart 1915 Çanakkale zaferinde rütbesi Tümgene$\mathrm{ral}^{18}$ olmuş ve birliğin başına geçmiştir.

“Çanakkale Boğazi’na yapılan ilk deniz taarruzu, 3 Şubat 1915 günü saat 06.50’de başlamış, Fransız ve Ingiliz harp gemileri ikinci kez 19 Şubat 1915 günü saat 07.45'te, Boğaz önüne gelmiş; uzak mesafelerden, girişteki Türk tabyalarını saat 17.30’a kadar topçu ateşi altına almıştı.25 Şubat 1915 günü daha fazla muharebe gemisi bombardımana katılmış, 26-27 Şubat 1915 günleri merkez tabyaları

15 ATASE, BDH Koleksiyonu, Kls. 4669, Dos. H-1, Fih.1-52; Birinci Dünya Savaşında... s. 25-26.

16 Şerafettin Zeyrek, "Çanakkale Savaşlarında Hava Gücü ve Hava Savaşları", Çanakkale Araştırmaları Türk Yıllığı Dergisi, S. 1, Çanakkale, 2003, s. 135.

17 ATASE, Kls. 4669, D.: H-3. Fih.1-53; Birinci Dünya Savaşında..., s. 33.

18 Görgülü, s. 62. 
da ateş altına alınmıştı. 1, 2, 3, 4 ve 12 Mart 1915 günleri de Boğaz içerisine giren Ingiliz ve Fransız harp gemileri, kayda değer bir başarı sağlayamadılar. Ingiliz Amirali De Robeck (dö Robek) tüm deniz gücüyle Boğaz' zorlayarak İstanbul'a ulaşmaya karar verdi. 18 Mart 1915 sabahı Íngiliz ve Fransız filoları, tam yolla ve büyük bir güvence içinde Boğaz'a girdiler, saat 08.30'da, Anadolu ve Rumeli kıyılarındaki Türk tabyalarını bombardımana başladılar. Çanakkale Boğazı'nın iki yakasında mevzilenmiş bulunan Türk topçularının açtı̆̆ yoğun ateşler ve karanlık limana dökülen mayınların etkisiyle mevcudunun \% 35'ini yitiren İniliz ve Fransız harp gemilerinden oluşan bu donanma, saat 17.30'da çekilmek zorunda kaldı. Yalnız bugünkü muharebede Bouvet (Buve), Ocean (Oşın), Irresistible (Irrezistibil) muharebe gemileriyle iki muhrip, yedi mayın arama gemisi batmış, Gaulois (Golva), Inflexible (Infileksibıl) de dahil olmak üzere yedi zırhl, görev yapamayacak duruma gelmiș, bunlardan bazılarının yedeğe alınarak muharebe alanından uzaklaştırılması gerekmişti. ${ }^{19 ”}$

18 Mart 1915 tarihi; Çanakkale Boğazı'nı geçmeye teşebbüs eden Amiral J. De Robeck komutasındaki İngiliz ve Fransız donanmalarının, ağır zayiat vererek başarısız kalışı düşman donanması 7 saat süreyle tüm boğaz tahkimatını ateş altına almışsa da, bu girişim, kıyı topçusunun etkili karşı ateşi sayesinde sonuçsuz kalmıştır. Bu deniz savaşında Nusret Mayın gemisinin döşediği mayınlar düşman donanmasına ağır kayıplar verdirmiştir. ${ }^{20}$ Müstahkem Mevki Komutanı Cevat Paşa her yönüyle üstün nitelikli bir kişiydi, birleşik filo büyük deniz harekâtını plânlarken, O da Nusret Mayın gemisine karanlık liman bölgesini mayınlatıyordu. ${ }^{21}$

Cevat Paşa'nın Mustafa Kemal Paşa’yla Çanakkale Deniz savaşları esnasındaki görüşmeleri ve Mustafa Kemal Paşa'nın bu konudaki düşünceleri de önemli bir ayrıntıdır. 18 Mart öncesinde cephede bir araya gelen bu iki komutan bu savaşın bir ölüm kalım savaşı olacağını çoktan anlamışlardı. Düşman ordusu tüm gücüyle saldırıya geçmişti. 1918 yılında Ruşen Eşref tarafından Yeni Mecmua'da neşredilmiş beyanatında şu bilgiye yer verilmiştir: "Mustafa Kemal Paşa, kendisinin Maydos (Eceabat) mıntıkası kumandanlığı esnasında cereyan eden mühim vakaları şu suretle hülasa etti:

“düşman bir defa Seddülbahir'e ve Kumkale’ye asker çıkarmak teşebbüsünde bulunuyor... Sahil müdefası Cevat Paşa Hazretlerinin tahtı emrinde bulunuyordu. Benim bu hareketle alakam dolayısıyladır. Yalnız 5 Mart günü sabahı Cevat Paşa Hazretleri Maydos'ta bulunan karargahıma gelmişti. Kendisine Seddülbahir sahil mintıkasındaki tertibatı göstermek üzere beraber Kirte'ye gittik. Oraya var-

19 Baycan, s. 376.

20 Utkan Kocatürk, Doğumdan Ölümüne Kadar Kaynakçalı Atatürk Günlüğ̈̈, Ankara 2007, s. 36.

21 Baycan, s. 376 
diğımız zaman, düşman donanmasının Kirte ve Alçıtepe istikametlerine açtığı ateşin altında kaldık."22 Mustafa Kemal Paşa kendi notlarında da olayın devamı için şunları söylüyor: “ ...bunun üzerine ben mezkur mıntıkanın muhafazasına memur olan 26'ncı alay kumandanına müteyakkız (uyanık, gözü açık, tetikte) bulunması için bazı talimat-ı şifahiye verdikten sonra Cevat Paşa vazifesi başında bulunabilmek üzere Maydos'a avdet ettik." ${ }^{23}$

Çanakkale cephesinde hem karadan hem de denizden savunma için Mustafa Kemal Paşa ile Cevat Paşa'nın komutasındaki birliklerin yaptıkları tüm askeri açılımlar birbirini tamamlar nitelikteydi. Her iki komutan da (Çanakkale Savaşlarında, Cevat Paşa'nın askeri rütbesi Mustafa Kemal Paşa'nın üstündeydi) bu cephe hakkında bilgi alışverişlerini eksik etmemiş, neler yapılacağı hususunda görüşmelerde bulunmuş ve pek çok önemli konuda hemfikir olmuşlardır.

Düşman işgali üzerine Mustafa Kemal'in öngörüsünü de kendi notlarında şu şekilde aktarmaktadır:

“Bu kuvvet mühim düşman teşebbüsüyle mütenasip hadden ve kendisinin donanma ateşinin muharip tesiratına karşı tahaffuz edecek ve ancak düşman piyadesinin sahile takarrüp (yaklaşma, yanaşma) ve huruca başlaması anında faaliyete geçebilecek tedabir ve tertibattan mahrum bulunduğu takdirde, tehlikenin bertaraf edilmesini müşkül görüyordum. Bu mülahazatımı 5-1-31 günü birlikte Kirte'ye hareket ettiğimiz sirada dahi mevki-i müstahkem kumandanı Cevat Paşa'ya izah etmiștim. Kendileri Seddülbahir mıntıkasının pek dar olmasından düşmanın kuvay-ı mühimmesine cevelangah (dolaşma yeri, savaş yeri) olamayacă̆ı kanaatinde bulunduğunu beyan etmişti.”24

Cevat Paşa içinde husus aynı çerçevede oluşuyor, O'nun tasarladığı plan düşman donanmasını şaşırtmak, donanmanın hasar görmesi ve geri çekilmelerinin sağlamak yönünde olacaktı. Boğazın en dar kısmında uygulanacak teknik, düşmanın manevra kabiliyetini kısıtlayacağından mutlak bir başarıyla sonuçlanabilirdi.

1915’te Çanakkale'nin başarısızca geçilmeye çalışılması kadar ilgi toplayan ve üzerinde çalışılan bir harekâta iki dünya savaşında da rastlanmadığını söylemek pek

22 Uluğ İ̆gemir, Anafartalar Muharebati'na Ait Tarihçe, Ankara 1990, s.X-XI; İğdemir, "Atatürk'ün Anafartalar Hatıraları", BELLETEN, C.VII, Ankara,1943, s.28; Hüsamettin Öztürk, " Çanakkale'nin Mustafa Kemal'in Askeri Kariyerindeki Yeri”, 85. yilında Çanakkale Savaşları Sempozyumu, (23-24 Mart 2000 Çanakkale) Sempozyum Bildirileri, 18 Mart Üniversitesi Çanakkale Savașları Araştırma Merkezi, Çanakkale, 2000, s.79; Senem Güven, Hatırat Türü Eserlerde Çanakkale Muharebeleri, (Yayınlanmamış Yüksek Lisan Tezi), Ankara, 2007, s.47

23 Mustafa Kemal, Arıburnu Muharebeleri Raporu, (Yay. Hzr. Uluğ İğdemir), Ankara,1990, s.3

24 Mustaf Kemal, s. 9 
yanlış olmaz. Sir Edward Grey şöyle yazıyordu: 'Gelibolu'daki harekât kadar hiçbir şey, boyutları bu kadar çarpıtmamış, tarafsız değerlendirme yeteneğini bu kadar bozmamış, stratejik değerler doğrusunu bu kadar sakat bırakmamıştır." Çanakkale'de kazanılan zafer, tükenmekte olan Osmanlı'nın son kıpırdanışı; Millî Mücadelenin ateşleyicisi ve ilhâm kaynağı olmuştur. ${ }^{25}$

Mücadeledeki başlangıç altı ay öncesine ait ise de, sonuca 18 Mart 1915'te ulaşılmıştır. 6 Ağustos 1914’ten 27 Şubat 1915’e kadar dört Türk gemisi (Selanik, İntibah, Nusret, Samsun) Kepez burnundan Çanakkale önlerine kadar uzanan on mayın hattına toplam üç yüz yetmiş yedi mayın döşemiş ve bu saha top ile takviye edilmişti. Düşman denizaltılarına karşı etkili savunma tedbirleri de alınmıştı. 2 Mart 1915’te, Alman General Liman von Sanders, buradaki orduların başına getirilmişti. ${ }^{26} 18$ Mart 1915 başarısı Türk ordusunun ve komutanlarının başarısıyla doğrudan ilgilidir. Cevat Paşa'nın deniz harekatında ki askeri planlaması düşman gemilerinin deniz yoluyla Çanakkale'yi geçememesine ve geri çekilmelerine sebep olmuştur. Bu başarı dünya basınında da büyük yankı uyandırmıștır. Churchill’in Times gazetesinde Nusret Mayın Gemisi hakkında verdiği beyanatta dikkat çeken bir cümle savaşın bu aşamadaki durumunu özetler niteliğindedir: "18 Mart'ta dünya kara sularında 5 binin üzerinde gemi hizmet veriyordu. Nusret' in yaptlğı bir yana, 5 bin geminin yaptığ bir yana.”

Mart 1915 başlarında Çanakkale Müstahkem Mevkii emrinde 27 batarya halinde teşkilâtlanmış çeşitli çapta 104 top ve bir de mayın grubu vardı. Topların bir kısmı savaş gemilerinden çıkarılmış gemi toplarıydı. Tüm eksikliklere rağmen 18 Mart tarihini önemli kılan bir husus da budur: Kesin olarak yenilecek gözüyle bakılan Türk ordusu, her türlü eksik materyallere rağmen en ufak ayrıntıyı bile kullanarak değerlendirmiş ve tarihe büyük bir başarı notu düşürmüşlerdir. 18 Mart'ta Çanakkale'yi denizden geçemeyeceğini anlayan düşman kuvvetleri planlarını kara harekatına yönlendirmişlerdir. Bu başarının diğer bir başlığıyla konuyu daha açıklayıcı hale getirmek gerekir. Çünkü 18 Mart kahramanlığının ayrıntılarında hiç kuşkusuz $\underline{\text { Nusret }}$ Mayın gemisi yer almaktadır.

\section{2. Çanakkale Deniz Savaşlarında Cevat Paşa ve Amiral Robeck Savaşı: "Nusret Mayın Gemisi"}

Şubat 1915 tarihinden itibaren İtilaf Devletlerinin Çanakkale'ye yapmış oldukları harekâtın kesin zafere ulaşamamasındaki önemli bir ayrıntıya dikkat çekmemiz gerekmektedir. Nusret Mayın gemisiyle ciddi bir askeri strateji uygulayan Cevat

25 Hayri Öztürk, “Servet-i Fünün'da Çanakkale Zaferi”, TÜBAR Dergisi, S. XII, Güz,2002, s. 75-76; http://www.eceabat.gen.tr/popup/10.asp

26 Ahmet Halaçoğlu, "Birinci Dünya Savaşında Türk Donanması ve Çanakkale Deniz Operasyonları", Askeri Tarih Bülteni, Ankara 1988, s. 25. 
Paşa’nın, Amiral Robeck'e karşı kazandığı savaş, tarihe düşülecek önemli bir ayrıntıyı oluşturmaktadır.

Rusların 1 Kasım 1914’te Kafkaslardan taarruz ederek Türk doğu sınırı üzerinde savaşı başlatmalarının hemen ardından, İngiliz ve Fransız gemisinden oluşan 18 gemilik Birleşik Filo, 3 Kasım 1914 sabahı Boğaz'a yaklaşmıștır. Bunlardan sadece dördü saat 06.45 'ten itibaren Boğaz'ın giriș tabyalarından Seddülbahir ve Kumkale Tabyalarını yaklaşık 14.000 (on dört bin) metre mesafeden 17 dakika bombardıman etmiştir. ${ }^{27}$

Birleșik Filo'nun Boğaz giriş tahkimatını bu ilk bombardımanı, burada bir sonuç almaktan ziyade Rusya'dan sonra İngiltere ve Fransa'nın da Osmanlı Devleti'ne karşı savaşı başlatma, başka bir deyişle savaş ilanı anlamını taşıyordu. ${ }^{28}$ Daha önceleri Türk donanmasının eğitiminde görev almış bulunan İngiliz Amirali Limpus'un, Türkiye'yi vaktinden önce uyaracağı endișesiyle bu bombardımana karşı çıkmasına rağmen, Churchill'in emriyle yapılan bu harekat, Türkiye için ciddi bir uyarı olmuştur. Nitekim o tarihte Çanakkale Müstahkem Mevki komutanı olan Cevat Paşa, bu konuyla ilgili olarak "Bu bombardıman beni uyandırdı. Bütün zamanımı her yola başvurarak savunmayı düzeltmeye ayırdım." Demişti. ${ }^{29}$ Hemen harekata geçmekten yana olan Churchill'in direktifleriyle Birleşik Filo donanması savaşa erkenden hazırlanmıștı. Bundaki iki etken:

1) Türk ordusunun yenileceği düşüncesi,

2) İngiliz Amirali Limpus'un, Türkiye'yi vaktinden önce uyaracağı endișesinin yer aldığını söyleyebiliriz.

İtilaf donanması, 18 Mart 1915'te denizden gerçekleştirdiği büyük saldırıda başarısız olup geri çekildi. Bu defa kara harekatı ile Boğaz kıyısındaki mevzileri düşürüp İstanbul'a ulaşmak istediler ve yine başarısız kaldılar. 1915 yılı sonunda tamamen çekildiler. Çekilirken tesellileri, Türkleri Çanakkale'de oyaladıkları, diğer cephelere yardımcı olduklarıydı. Gerçekte Çanakkale'de yenilmekle kalmamış, savaşın insiyatifini de kaybetmişlerdi. ${ }^{30} \mathrm{Bu}$ tam anlamıyla İtilaf güçleri için hayal kırıklığının yanında büyük bir prestij kaybı da olmuştur. Birleşik Filo’nun yenilmesi İtilaf güçlerinin savaş planlarında yer almamış olasılığı da hesaplanmamış bir durumdu. Yenilgi bu yüzden İtilaf güçleri açısından büyük bir hüsran olmuş; Türkler açısından da umudun, hayalden öte gerçeğe dönüşebilmesi ihtimalini doğurmuştu.

27 Birinci Dünya Harbi’nde Türk Harbi Çanakkale Cephesi Harekatı, V. Cilt . Kitap,(Yay. Krl. Bşkn. Kamil Başoğlu), Ankara 1993, s. 99-100.

28 Birinci Dünya Savaşı'nda Çanakkale Cephesi V. Cilt, III. Kitap, (Yay. Krl. Bşkn. Kamil Başoğlu), Ankara, 2012, s. 5.

29 Birinci Dünya Savaşıı̇inda... s. 101.

30 Rahmi Doğanay, "Çanakkale Zaferinin Türk ve Dünya Tarihi Açısından Önemi”, Atatürk Yolu Dergisi, c. 3, S.12, Ankara, 1993, s. 365. 
“20 Mart 1915’te Müstahkem Mevki komutanı Cevat Paşa, İngiliz ve Fransızların Boğaz muharebelerinde uğradıkları yenilgi karşısında, karadan büyük bir çıkarma harekâtına girişebileceklerine işaretle, Başkomutanlığa mevcut savunma düzenini tamamlayıcı bir değişikliğe gidilmesini önermiştir. Amiral Robeck kumandasındaki düşman filosu, Cevat Paşa kumandasındaki Çanakkale istihkâmlarına karşı, hücuma geçti. Bu ilk hücumun maksadı hem mayın tarlalarını koruyan bataryaları tahrip etmek, hem de boğazın orta kısmındaki tabyaları susturmaktı. Bundan sonra donanmanın asıl kısmı rahatça boğazı geçerek Marmara'ya açılacak ve oradan İstanbul'a gelecekti. Fakat Cevat Paşa, düşmanın hareketlerini gözden kaçırmıyordu. Nitekim boğazın aşağı kısımlarını düşman mayın tarayıcıları tarafından tamamen mayından temizlenmiş olduğunu öğrendiği için, bir saldırının çok yakın olduğunu kestirmişti. Her ne pahasına olursa olsun, düşman gemilerini boğazdan geçirmemek lazımdı. Çünkü muazzam müttefik filosunun Çanakkale'yi geçerek Marmara'ya açılması, doğrudan doğruya imparatorluğunun başkenti İstanbul'un düşmesi demekti. Bu da daha harbin başında yenilmekten başka manaya gelmezdi. ${ }^{31}$ "

Müstahkem Mevkii Komutanı Cevat Paşa'nın Boğaz savunması için yaptığı savunma planında; Birleşik Filo gemileri ile yapılacak savaşı Kumkale-Kepez arasındaki deniz alanında kabul edecek şekilde hazırladığını görmekteyiz. Böyle bir planda gemilerin Kumkale-Kepez arasındaki orta bölgede yani Erenköy koyunun açılarında bulunmaları gerekmektedir. Bu mevkide savaşan gemilerin ihtiyaç duyacakları örneğin harp sahasını geçici olarak terk etmek gibi bir manevra durumunu, diğer gemilerin savaşma kabiliyetlerini aksatmadan en kısa yoldan yapması gerekmektedir. Bahse konu coğrafi saha için manevra yapabilecek tek alan Erenköy koyudur. Bunun yanında bir mayın hattının döşenmesinde, hattın düşman gemilerinin kuvvetle muhtemel ilerleme hattına en az bir mayına çarpabilmesi için dik olarak yerleştirilmesi esası da ortaya konduğu zaman Nusrat'ın dökeceği mayınların şekli ile ilgili tek bir sonuç ortaya çıkmaktadır. Bu şekilde Erenköy Koyuna Kumkale-Kepez hattına paralel olacak bir durumda oluşturulmasıdır. ${ }^{32}$

Çanakkale müstahkem mevki komutanı Cevat Paşa hatıralarında şöyle anlatıyor:

"18 Mart sabahı düşman donanmasının taarruz edeceği hakkında bir malumat yoktu. O sabah Büyük Önder Atatürk'le beraber Seddülbahir mıntıkasında bulunan bir piyade alayını teftiş ediyorduk. Sahaya vardığımız zaman alayda hiçbir hazırlığa tesadüf etmedik. Sadece karşımıza çıkan bir mehmetçik-düşman do-

31 Orhan Ş. Yüksel, "50 Yıl Önce Çanakkale Savaşını Kazandık", Tarih Mecmuası, Cilt 1, S. 2, İstanbul,1965, s. 7.

32 M.Haluk Çağlar, “Çanakkale Deniz Muharebelerinde Mayın Harbi ve Nusrat'ın Mayın Döküş Harekatı", www.geliboluyuanlamak.com. (13.03.2010) 
nanmast geliyor- dedi ve siperine girdi. Gözlerimiz ufukta idi. Düşman donanmasının yavaş yavaş methale (girişe) doğru ilerlediğini gördük. Hemen geri döndük. Maydos'ta Atatürk'ten ayrlldım. Bir motora atlayarak Çanakkale’ye geçtim ve doğru tarassud (gözetleme)mahalline gittim" ${ }^{33}$

Martın ilk günlerinde her iki komutan, olası şiddetli bir saldırının yakın tarihte gerçekleşeceğini anlamışlar, alınacak tedbirlerin ivedilikle yerine getirilmesinin gerekliliği hususunda da ortak kanaatlerde birleşmişlerdi.

İngilizler, 1915 yılı başında Avrupa'daki harp mevzi harbine dönüşünce bütün kuvvetlerini Avrupa cephesine yığmaktansa Çanakkale veya Balkanlar'da ikinci bir cephe açarak harbi hareket harbine çevirmeyi, bu suretle, Rusya'ya ihtiyacı olan yardımın yapılabileceğini, İstanbul'un ele geçirilmesiyle Osmanlı Devleti'nin Almanya'dan kopartılabileceğini ayrıca harbe girmekte kararsız görünen Bulgaristan'ın da Almanya tarafında harbe girmesinin önleneceğini düşünerek, Çanakkale Boğazı'nın donanmayla geçilmesine ve İstanbul'un işgaline karar verdiler. ${ }^{34}$ İngiliz tarafindaki düşünce açık ve nettir. Osmanlı Devleti’nin, deniz gücünün, kıyılarını ve boğazı koruyamayacağını planlayan ve kilit nokta olarak Çanakkale boğazını gören düşman kuvvetleri, uğrayacakları yenilgiyi bu planlarına dahil etmedikleri ortadadır. ${ }^{35}$

Çanakkale Savaşı’nın kazanmamızda sahil tabyalarının olduğu kadar Nusret Mayın $^{36}$ gemisinin de büyük rolü olduğunu söylemiştik. Bu küçük gemi, düşman taarruzundan önceki günlerde, gemilerin manevra yaptığı Karanlık Liman'ın yukarı kesimlerine gizlice mayın döşerdi. 18 Mart sabahı başlayan taarruzda yarım gün içinde 6 zırhlının birden yok olması, düşman filosu için çok ağır bir darbeydi. Bu ağır kayıplar üzerine filo, boğazdan çekildi ve Cevat Paşa komutasındaki Çanakkale istihkâmları, düşmana karşı beklide bütün savaşın gidişine tesir edecek galibiyeti kazandı. Bunun üzerine İngilizler, bahriye nazırı Churchill'in emriyle dünyanın en büyük harp gemisi olan, Queen Elizabeth dretnotunu, herhangi bir kazadan korumak için, Çanakkale'den çektiler. ${ }^{37}$

"İngiliz General Oglander'in “Çanakkale-Gelibolu Askeri Harekatı” adlı eserinin 1. cildinde:

33 Yaşar Semiz, "18 Mart Çanakkale Deniz Savaşı: Sebepleri, Gelişimi ve Sonuçları", Türkiyat Araştırmaları Dergisi, Selçuk Üniversitesi, S.14, s.269

34 Görgülü, s. 62

35 www.canakkalekutup.gov.tr

36 Nusrat Mayın Gemisi, 1912 yılında Almanya'nın Kiel şehrinde Germenia tezgahlarında inşa ettirilmiștir. Eni: 7,4 m. Boyu: 40m. Çektiği su: $2 \mathrm{~m}$. Sürati: 15 mildir. Bu tekne dar alanlarda kolayca manevra yapabiliyor ve az su çektiğinden mayın alanları üzerinde güvenle dolaşabiliyordu. Gemi 3 Eylül 1914’te Çanakkale'ye getirildi. Ayşegül İnanç, Nusrat Mayın Gemisi, canakkalektp.kulturturizm.gov. tr (21.02.2012); Murat Duman, Cumhuriyetimizin Önsözü Çanakkale Savaşlar Hatıralar ve Kahramanlar, İstanbul 2006, s. 55-56

Yüksel, s. 7-8. 
"Pek uygun başlamış olan gün bu meçhul mayın hattının olağan üstü ve ortalığı kırıp geçiren başarısı yüzünden, tam bir başarısızlıkla sona erdi. Bu yirmi mayının seferin talihi üzerindeki etkisi ölçülemez." Bahriye Nazırı Winston Chuchill 1930'da "Revue de Paris" dergisinde olayı şöyle yorumlamıștır: "Birinci Dünya Harbi’nde bu kadar insanin ölmesine harbin ağır masraflara maal olmasina, denizlerde onca ticaret ve savaş gemisinin batmasina başlica neden, Türkler tarafindan bir gece önce atılan o incecik çelik halat ucunda sallanan yirmi altı adet mayındır. Nusret'in gizlice döktüğ̈̈ bu 26 demir kap, savașın devamı ve dünyanin geleceği bakımından, diğer tüm çabalardan daha tam ve daha kesin sonuçtu. Hedeflere varmak içindi. Bu engel, Ingilizler tarafindan bașarıyla bașlatılmıș olan Çanakkale Operasyonunu durduran birçok psikolojik karışıklıklar doğurdu. Yalnız başına bu mayın engelidir ki Türkiye’yi bir yenilgiden kurtardı ve savașı uzattı." ${ }^{38}$

Düşman tarafından 18 Mart 1915 olayı bu çerçevede değerlendirilmesi, Nusret Mayın gemisinin döşediği mayınların savaş planlarını alt üst etmesini kabul ettiklerini göstermektedir. ${ }^{39}$ Neticede 18 Mart 1915 tarihinde Çanakkale'de tesis ettiği mayın hatları ile savaşın kaderini değiștiren kahraman gemi, "Nusret Mayın" gemisidir. Bunun en önemli komutanı da Cevat Paşa'dır. 100 gemi ve yaklaşık 250 ağır topa sahip olan Müttefik Donanması, üç hat şeklinde teşkilatlandırılmış olarak 18 Mart 1915 sabahı saat 10.00'dan itibaren Boğazı zorlamaya başlamışlarsa da istediklerine ulaşamamışlardır.

18 Mart 1915 Amiral Robeck, plan dahilinde Boğaz’ın sadece 1 mil genişliğindeki en dar noktasından komutasındaki 16 savaş gemilik dev donanma ile Çanakkale'yi geçmeye kalkmıştır. Ancak her gemi Türklerin Nusret Mayın gemisiyle boğazın Asya tarafına yerleștirdiği deniz mayınları tarafından hasar almıştır. ${ }^{40}$

18 Mart 1915 Çanakkale Deniz Savaşlarında, düşmanın planlarının değişeceği gün öncesinde Müstahkem Mevki Karargâhında bulunan Cevat Paşa, tarihi bir karar alacaktır ve 26 adet mayının Erenköy koyu mevkiinde yeni bir hat boyunca döșenmesini isteyecektir. Çünkü; Müttefik Donanmanın Çanakkale Boğazı’ndan girmesi muhtemeldi. 11'nci hat olarak yeni bir mayın hattının tesis edilmesine bu anlamda ihtiyaç duyulmuştur. Müttefik Donanma tekrardan harekete geçecekti. Bu defa planlarını kesin olarak gerçekleştirmeye çalışacaklardı. 7 Mart'ı 8 Mart'a bağlayan gece Nusret Mayın Gemisi Yüzbaşı Tophaneli Hakkı Bey ve Müstahkem Mevkii Mayın Grup Komutanı Yüzbaşı Hafız Nazmi (Akpınar) Bey komutasında Erenköy Koyu ön-

38 İnanç, a.g.m, (21.02.2012)

39 Cevat Paşa'nın Çanakkale deniz savaşlarında göstermiş olduğu başarıya ilişkin olarak 24 Mart 1915'te Tanin Gazetesinde II. Kaizer Wilhem’ın, Enver Paşa'ya gönderdiği Cevat Paşa Hakkındaki Düşüncelerini İçeren Telgrafın Haber Metni Ek:1 de verilmiştir.

40 Ali Sarıkoyuncu, Esra Sarıkoyuncu Değerli, "Avusturya Basınında Çanakkale Muharebeleri”, ATAM Dergisi, Cilt. 25, S.73, Ankara 2009, s. 48. 
lerinde Karanlık Limana, yüzer metre aralıklarla 26 mayın dökerek, diğer 10 hattan farklı şekilde, sahile paralel yeni bir mayın hattı tesis etmiştir. 280 tonluk Nusret mayın gemisi altı subay ve 54 erle denize açıldı. Cevat Paşa'nın talimatıyla Saat 03.20'de 26 mayını döșemişti. ${ }^{41}$

3 ncü Kolordu Komutanı Esat Paşa (Korgeneral Bülkat), "Düşman donanmasina Çanakkale Boğazı'na yaklaşmak ve Boğaz’ zorlayıp İstanbul'a gelmek firsatını vermeyenlerin birincisi Cevat Paşa ikincisi ben, kesin sonucu sağlayanı da Anafartalar Komutanı Mustafa Kemal Paşa'dır" diyor. ${ }^{42}$

Cevat Paşa, Müstahkem Mevkii Komutanı olarak atandığı Çanakkale'de göstermiş olduğu üstün başarısı tarihe yazılmıştır. Bu göreve atanmasının ardından Boğaz'in savunmasını ele alır. Zira Boğaz savunma planları yoktur ve Müstahkem Mevkii kumandanlığı stratejik açıdan perişandır. Yarbay Selahaddin Adil Bey, Müstahkem Mevkiinin durumunu apaçık belirtiyor: "İtalya ve Balkan seferinde yapılmış olan hazırlıklar, mevkiinin evvelki kumandanları tarafından hazırlanmış bir müdafaa planı yoktu. Her şeyi yeniden hazırlamak lazımdı." 43

"Yeni baştan savunma planları oluşturulmaya başlandi. Cevat Paşa'nın göreve gelmesiyle kadro dişına çıkarılan bataryalar yeniden tanzim edildi ve tabyalardaki toplar tekrar kuruluşa alındı. ${ }^{44 " ~ B u ~ b a t a r y a l a r a ~ a s k e r ~ v e ~ s u b a y ~ y e r l e s ̦ t i r i l d i . ~ M e v c u t ~}$ batarya ve tabya kadroları değiştirildi. Tüm bu çalışmalar yapılırken; Selahaddin Adil Bey, Cevat Paşa'nın bu durumunu şöyle özetleyecektir: "...Cevat Paşa, hiçbir zaman kararsız ve ümitsiz olmadı." ${ }^{45}$ Bunun da ispatını 18 Mart'ta görmekteyiz.

Çanakkale cephe savunması İstanbul'un ve dolayısıyla Osmanlı Devleti'nin tüm topraklarının da savunulması anlamına gelmekteydi. İtilaf güçleri, Çanakkale Boğazını çok rahatıkla geçebileceklerini düşündüklerinden artık Osmanlı Devleti üzerinde yapılan planların da sonuca varacağından asla șüphe duymuyorlardı. İște bu açıdan da Çanakkale Deniz Savaşı son derece önem arz etmektedir.

Çanakkale'nin İstanbul'a uzaklığı 150 deniz milinden biraz fazladır. Çanakkale Boğazı'nın düşme ihtimalinin daha yakın olarak hissedildiği 19 Şubat- 18 Mart 1915'te bombardımanların İstanbul'da Hükümet, Saray ve halk nezdinde etkileri görülecektir. Öncelikli olarak Çanakkale'den gelen haberler üzerine Sultan ve hanedanın taşınması

41 Cevat Paşa'nın mayın döşenmesiyle ilgili olarak anlatılan olayın anekdotu için bankız: Erdal Şafak, Atını Dinyester'de Sulayan Komutan, www.sabah.com.tr, (2006/12/10)

42 Baycan, s.380; Bkz.:Esat Paşa'nın Çanakkale Hatıraları, Haz.: İhsan Ilgar, Nurer Uğurlu, 2. Baskı, Örgün Yayınevi, İstanbul, 2004

43 Selahaddin Adil Paşa, Çanakkale Cephesinden Mektuplar-Hatıralar, (Yay. Hzr. Muzaffer Albayrak),1. Baskı,İstanbul,2007, s.25; Ahmet Yurttakal, 18 Mart Kahramanı Cevat Paşa, www.geliboluyuanlamak.com, (09/04/2009)

44 Yurttakal, a.g.m. (09/04/2009)

45 Mustafa Albayrak, Atatürk ve Türkiye Cumhuriyeti’nin Tarihsel Gelişimi, Ankara, 1999, s.24 
planları yapılırken şehrin savunulması için çalışmalar yapılır. İstanbul'da Yeşilköy ve Sarayburnu arasına muhtelif bataryalar yerleștirilir. Marmara sahillerine müfrezeler gönderilir. Boğaz’nn geçilmesi durumda düşman donanmasının harekâtı izlenecek, gerekli tedbirler buna göre alınacaktır. ${ }^{46}$ Tüm alınan tedbirler yapılan tüm planlar Bağaz'ın geçilebileceği doğrultusunda düşünülmüştü. 18 Mart tarihi bu açıdan bir güven tazeleme, yeni bir umudun ortaya çıkması demekti. Cevat Paşa'nın buradaki konumu ve başarısı sadece kazanılmış bir deniz savaşı değildi. Saltanatın ve Osmanlı Devleti'nin kalbi olan İstanbul'un da karşılaşacakları büyük tehlikeden dönmesiydi. Bu tarihi savaş ve sonucunda gelen başarı Cevat Paşa'nın da takdire mazhar olmasına neden olmuştur. ${ }^{47}$ Ayrıca Cevat Paşa'ya Çanakkale Deniz Savaşlarındaki başarılarından dolayı Alman nişanı da takdim edilmiştir. ${ }^{48}$

Cevat Paşa, eldeki mevcut imkânları kullanarak yeni bir askeri stratejiyle Boğaz'ın savunmasını gerçekleştirecektir. İşte; Çanakkale Deniz Savaşlarında ki başarı da Cevat Paşa'nın dirayeti, inancı ve kararlılığıyla aynı doğrultu da sonuçlanmıştı. Çanakkale Deniz Savaşları yıkılacak gözüyle bakılan Osmanlı Devleti’ne güç katmıştır. Cevat Paşa'nın buradaki rolü sadece düşman gemilerinin boğazdan geçirilmemesi ile uyguladığı askeri bir başarı planıdır demek eksik bir söylem olur. Şayet orada uygulanan plan istenildiği gibi olmasaydı Çanakkale Cephesinde düşman zırhlıları rahatça boğazı geçebilecek, savaş öncesi Osmanlı Devleti üzerinde yapılan planlar ivedilikle gerçekleşmeye başlayacaktı. Kara harekatında da yapılan askeri strateji yarım kalacaktı. Cevat Paşa'nın Çanakkale Deniz Savaşlarındaki kazanımıyla Mustafa Kemal Paşa'nın kara harekatı tam bir bütün olarak değerlendirilmelidir. Boğaz'dan geçemeyen düşman donanmasının hayal kırıklığı ve geri çekilmesi Türk ordusunun artan umudu karşısında İtilaf Devletlerinin bu cephedeki mağlubiyetleri savaşın pek çok açıdan çok önceden planlanan seyrini de tümüyle değiştirmiştir.

\section{Cevat Paşa'nın Anılarında Çanakkale Cephesi: Mehmetçik ve Mustafa Kemal Paşa}

Çanakkale Savaşı'nda Müstahkem Mevkiin savunmasını yöneten Cevat Paşa o günlerle ilgili olarak bazı anılarını anlatmıştı. 1936 yılında Yedigün Dergisi'nde kendisiyle yapılan röportajda Çanakkale Savaşlarıyla ilgili yaşadıklarına ve düşüncelerine yer verilmiştir. Bunlardan bazı başlıklar dikkat çekicidir. Her savaş kahramanını da

46 Lokman Erdemir, "Çanakkale Boğazında İlk Bombardımanlar ve İstanbul”, 1453 İstanbul Kültür ve Sanat Dergisi, S. 21, s. 16, İstanbul, 2015; Mustafa Selçuk, Hedef Şehir İstanbul, Emre Yayınları İstanbul 2005, s. 47-50

47 Ek: 4'te iki örnek metin verilmiştir. Baycan, s. 388-389.

48 Ek:5 Almanya Devleti tarafından Bahr-ı Sefid Boğazı Kumandanı Cevat Pașa'ya ikinci rütbeden Croix de Fer nişanı verildiği anlatılmaktadır. Osmanlı Belgelerinde Çanakkale Muharebeleri 1, (Proje Yönetici Yusuf Sarınay), Belge:54, Ankara 2005, s. 64. 
ortaya çıkarır ancak bazı savaşların kahramanları saymakla bitmez. Çanakkale Cephesinde yaşanan da buydu. Özellikle Mehmetçiğin buradaki duruşu, maneviyatı çok başka bir boyuttur. Bu konuyla ilgili olarak “Çanakkale'de Mehmetçik yok muydu?” sorusuna Cevat Paşa şu şekilde cevap verecektir: "Mehmetçik olmasaydı Çanakkale olur muydu? Çanakkale harbi diğer sahalarda yapılan harplerle kabili mukayese değildir. Tasavvur buyurun... Denizde bir harp oluyor... Fakat ötede karada üç dört kilometrelik bir sahada da insanlar birbirlerine giriyorlar. Ve Mehmetçik orada da gıdasından bile mahrum olduğu halde memleketin kapısını beklemekten büyük bir zevk duyuyor." 49

Cevat Paşa, Çanakkale Savaşlarındaki anılarında Mustafa Kemal Paşa hakkında da şunları söylüyor:

“ Illk gün Atatürk'le beraberdik. O kara cihetine, ben deniz cihetine merbuttuk. Seddürbahir'e gittik, orada kıtaatı teftiş edecektik. Yolda kıtaatın teftiş için hazır olmadı̆̆ını anladık. Uzakta düşman donamasının şimdiye kadar olduğu gibi değil, fakat, ciddi bir harp gayesiyle ilerlemekte olduğunu gördük, geriye döndük. Alçıtepe yolunu tuttuk. O sırada ilk düşman mermisi başımızın üzerinden gerçek Alçıtepe'ye düştü. İște 5 Mart sabahı böyle başlamıştı. Muhakkak ki Çanakkale'de en parlak günümüz budur. Bu sabah, müttefikin donanması olanca kuvvetiyle, şiddetiyle Kaleye taarruza başladılar. Elimizde mermi miktarı mahdut olmakla beraber bunlarda ve kara ordusu topçularından, bilhassa obüslerden azami istifadeyi düşünmüş ve bu sebeple mestur mevziler hazırlamıştık. Her tabya ve her batarya kendilerine evvelce verilmiş olan talimat mucibince faaliyet sahası dahiline giren düşman gemilerine hemen ateş açıyorlardı. ${ }^{50}$

Cevat Paşa hatıralarını anlatırken, yıllar sonra, 18 Mart 1915 gününün en kıymetli anı sorulduğu zaman: “...o gün güneşin son ışıklarıyla Boğaz'dan perişan halde çıkmakta olan düşman filosunun görünüşü idi." ${ }^{51}$ Diyecektir. O, yaşamış olduğu askeri alandaki üstün başarılarında her daim Mehmetçik kuvvetinden bahsediyordu. Almış olduğu övgüler ve madalyalardaki maneviyatın Cevat Paşa için ayrı bir yeri olacaktır. Anılarını anlatırken, kendisini tarihe "18 Mart Kahramanı" olarak yazdıran o günü de şöyle aktarıyor:

“...bu taarruz esnasında bize çok yardımı olan küçük bir mayın hattından bahsetmek isterim. 5 Martta kadar elimizde bulunan mayıları denize atmış ve hatları muntazaman tesisi etmiştik. Her iki tarafta bu hatların muhafazası için bataryalar yerleștirmiştik. 4 Martta elimizde kala kala 8 mayın kalmıştı. Bunların Karanlık limana götürülmesi

49 Yedigün Dergisi, 1936, No:180, s.14-15

50 Yedigün Dergisi, s.15

51 Glyasettin Yetkin, Yaratanların Ağzından 18 Mart 1915 Çanakkale Zaferi, Ankara, 1966, s.155 
emrini verdim. Düşman donanması ise böyle bir mayın hattının sahile muvazi tarza Karanlık limanda vücuduna imkan vermeyerek, manevralarını, ekseriyetle ateșten nispeten masun olan o sahada yapardl. Yinede öyle oldu ve böylece 8 mayının 5 Mart günü pek büyük yardımını gördük. Düşman donanmasının kaybettiği Buve, Irrezistbıl ve Oşin gemileri, mermi tesiriyle mi yoksa torpil temasıyla mı battılar, bunu tayin edebilmek vakıa müşkül ise de, herhalde bu 8 mayının o gün büyükçe bir rol oynadıklarını zannediyorum. Ogün Buve battıktan sonra düşman donanması ufak bir manevra yapmış ve buna müteakip ateşini tazelemişti. Akşama doğru Dardanos tan takriben 3 mil mesafede Irrezistbıl zırhlısı yana yatmış vaziyette Boğaz haricine doğru dönmek istiyordu. Dardanos'taki bataryamız ise ateş etmiyordu. Bu hal bizi şüphelendirdi. Telefon muharebatı sabahtan beri kesik olduğundan hemen Erkan-ı Harp zabitimi Dardanos'a gönderdim ve bu yan yatan geminin ateş altına alınmasını bildirdim. Meğer kahraman bataryanın kumandanı Hasanla topçu zabiti Mevsuf, şehit olmuşlar... civardaki topçu zabitlerinden birinin emir ve kumandasına verilen ve İrezistbıl'ı derhal ateş altına alan bu batarya o günden itibaren şehit kumandanların namına hürmetle Hasan Mevsuf adını almıştır. "52

Cevat Paşa, Dardanos Bataryası kahramanlarının son yolculuğa uğurlanırken; evlatlarım dediği Üst Teğmen Hasan ve Teğmen Mevsuf'un Değirmenlik mezarlığındaki kabirleri başında orada bulunanlara şöyle hitap ediyor: " Askerler, burada Hasan adında bir arkadaşımız yatıyor. Fani mevcudiyetinden daha çok işler beklenirken, şehit mertebesine erişip ebediyete intikal etti. Elbette bu zaferler bizi şerefli bir sulha kavuşturacak, hepiniz birer gazi olarak evlerinize döneceksiniz. Kumandanınız ve silah arkadaşım olarak sizlerden talep ediyorum: ilk doğacak oğlunuzun adını Hasan koyun ki O’nun içimizde yaşayan kahraman ruhuyla beraber ismini de ebediyen yaşatalım." 53

18 Mart Çanakkale Deniz Savaşı, Türklerin zaferiyle sona ermişti. Bu sadece donanma ile Çanakkale Boğazından geçmenin mümkün olmayacağını göstermektedir. Nitekim Amerikan Büyükelçisi Morgenthau raporunun bir yerinde: "Bu savașta hasar gören 10 ila 12 geminin yerine yenilerini sevk etmiş olsalar bile, aynı esaslarla gi-

52 Yedigün Dergisi, s.15-16; Cevat Paşa; Başkumandanlık Vekaletine 7 Nisan 1915 tarihinde göndermiş olduğu 707 numaralı yazıda Çanakkale Boğaz savunmasında fevkalade gayret gösteren ve 18 Mart 1915 Deniz Savaşında vazifesi başında şehitlik mertebesine ulaşan Dardanos Bataryası Kumandanı Kilitbahirli Üst Teğmen Hasan Hulisi Ef̧endi ve Tarassut subayı Trablusgarplı Teğmen Mevsuf Efendinin isimlerinin adı geçen bataryaya verilmesini ve Dardanos'un adının Hasan- Mevsuf Bataryası olarak değiştirilmesini talep etmiştir. 16 Mayıs 1915'te Başkumandanlık vekâleti, Cevat Paşa'nın bu talebini münasip görerek Dardanos Bataryasının adını Hasan-Mevsuf Bataryası olarak değiştirilmesine karar vermiştir. Birinci Dünya Harbinde Türk Harbi, Çanakkale Cephesi Harekatı, c.V. 1. kitap, Belge No:3, Ankara, 1993; İslam Özdemir, 18 Mart Özel Yazısı: Dardanos'a Şan Verenler, www. geliboluyuanlamak.com, (17/03/2011)

53 Mukbile Tarkan, "18 Mart Zaferi", s.2, (Sadeleștiren Nesrin Tarkan), Milliyet Gazetesi, (18 Mart 1970) 
rişilecek yeni bir hücumun akıbeti 18 Mart'takinden pekfarklı olmayacaktır." ${ }^{54}$ Cevat Paşa'nın da anılarını anlatırken işte bu noktaya devamlı dikkat çekmişti. Mehmetçik yani Türk askerinin sonsuz inancı, savaşın yönünü değiștiren büyük bir güç olmuștur.

Cevat Paş Çanakkale zaferi sonrasında asla kendini ön plana atmamış, sürekli askerlerin kahramanlıklarından bahsetmiştir: Şöyle der:

"...hatta o gece tabyalardaki bütün efrad gündüz ki müthiş yorgunluğa rağmen gece sabaha kadar çalışarak tabyaların harap olan yerlerini tamir etmişler, topları gömüldükleri toprak yığınlarından çıkarmıș, temizlemiş ve ertesi gün ateșe hazır vaziyete getirmişlerdi. Her ihtimali nazarı dikkate alarak ertesi güne hazırlanmıştık. Ben de bu çalışmaların birkaçına gittim. Herkes o karda büyük bir gayretle çalışıyordu ki, yorulduklarını hissettiklerimi adeta cebren oturtup dinlenmelerini temin edebiliyordum... Bunun için bazı yerlere gidemedim. Yanlarıda bulunmam onların daha fazla yorgun olmalarına sebep oluyordu." ${ }^{55}$

Tarihte birçok deniz zaferi kazanmış bir milletin ahfadı, en güçsüz olduğu bir dönemde hatta "Hasta Adam" dedikleri bir zamanda devrin yenilmez donamalarını perişan etmiş ve Düvel-i Muazzama'nın kuvvetlerini çekilmek zorunda bırakmıştır. İşte bu şanlı zaferin ardından birçok kumandan ve devlet adamı doğmuştur. Bu şanlı kumandanlardan Cevat Paşa, tarih sayfalarına Çanakkale Geçilmez sözünü yazdırdı. 18 Mart 1915'e kadar İstanbul'dan taşınmayı düşünen ve sürekli panik içinde olan padişah ve başkomutanlığa rağmen, Boğaz savunmasında dimdik duran Cevat Paşa, sonuna kadar üstün mücadele örneği gösterdi. Bu şanlı zaferin ardından 18 Mart Kahramanı ve İstanbul'u kurtaran birinci kişi unvanı ile anılacaktır. ${ }^{56}$

\section{Sonuç}

Birinci dünya savaşı yıllarında Osmanlı Devleti yıkılma sürecine girerken, vatanın bağımsızlığı ve itilaf devletlerinin emellerini boşa çıarmak için 18 Mart 1915 tarihi pek çok değerli ismi öne çıkaracaktır. İște bu isimlerden bir tanesi de Orgeneral Cevat Çobanlı Paşa'dır. Cevat Paşa almış olduğu askeri eğitimle beraber, yetişmiş olduğu Anadolu kültürüne ve Anadolu'nun tarihsel kimliğine sahip birisiydi. Sarayda Yaver olarak başladığı göreve, cephelerde komutan olarak devam etmiş Milli Mücadele yıllarından sonra açılan TBMM’de kısa dönem milletvekilliği dışında emekli olana dek askeri görevini bırakmamıştır.

54 Kemal Turan, “95. Yıldönümünde Çanakkale Zaferi”, ATAM Dergisi, Cilt: XXV, Sayı:73, Ankara, 2009, s. 70

55 Yetkin, s. 155; Yurttakal, (09/04/2009)

56 Yurttakal, (09/04/2009) 
Çanakkale Deniz Savaşlarında Çanakkale Geçilmez! sözünü yazdıracak, Birleşik Filo armadasının Türk askeri tarafından döşenen mayınlardan geçemeyerek geri çekilmesini sağlayacak ve 18 Mart Karamanı olarak tarihe geçecek bir önemli isimdir Cevat Paşa. Kendisi, İngiliz donanmasının ağır kayıplar vermesinde etkili bir askeri strateji uygulamıştır. Dönemin güçlü donanması, bu savaşta İstanbul'u ele geçirmek için hazırladıkları planı beklemedikleri bir anda gerçekleştirememişler ve geri dönmek zorunda kalmışlardı. Ne acıdır ki; 18 Mart'ta geçilemeyen Çanakkale, daha sonra İstanbul'un işgaliyle İngilizlerce savaşılmadan geçilmiștir. İște bu da yeni bir mücadelenin tam anlamıyla bağımsızlık mücadelesinin başlamasının temel nedenlerinden olacaktır. Cevat Paşa'da bu uğurda tıpkı Çanakkale Deniz Savaşlarında olduğu gibi sonuna kadar desteğini, mücadelesini verecektir. İyi eğitimli ve askeri dehası olan komutanlık vasfının yanında son derece vatansever biri olduğunu da gösterecektir.

Çanakkale Cephesi Savaşları muhakkak ki, deniz ve kara olarak iki kısımda değerlendirilmelidir. Çünkü bu iki başlık, Çanakkale Cephesinin gerçek profilini ortaya çıkarır. Öyle ki; Churchill'in planları, Birleşik Filo komutanı olan Amiral Carden tarafından desteklenerek büyük bir hazırlıkla son noktayı koyabilmek için Çanakkale Boğazı'na geldiler. Her şeyden önce daha yenilgi almamış bir İngiliz donanması gayet kendinden emin bir şekildeydi. Bunu Fransa donanması da destekleyince daha da güçlü bir donanma Çanakkale Boğazı'nda Türk ordusunu yenmek ve İstanbul'a geçmek üzere hareket etti. İtilaf Devletleri'nin deniz harekatı 19 Şubat 1915’te başladı. 13 Mart 1915’e kadar düşman gemileri tabyaları top ateşine tuttu, mayın tarama gemileri olabildiğince yol açtı. Boğazı zorlayarak geçebileceklerine inanan düşman kuvvetlerinin karşılarında kararlı ve dirençli bir savunma yapan Türk ordusunu görmeleri, bu işin o kadar da kolay olmadığını gösteriyordu. Bir ay boyunca yapılan binlerce mermi atışının ardından çok da büyük bir gelişme elde edilememişti. Cevat Paşa bu saldııılarda ivedilikle alınması gereken tedbirler üzerinde yoğunlaşmıștı. 18 Mart’a kadar geçen bu dönemde Boğaz’n girişinde bulunan Rumeli yakasındaki Seddülbahir ve Ertuğrul tabyaları ile Anadolu yakasındaki Kumkale ve Orhaniye tabyaları tahrip edilmişti. İtilaf güçlerince Boğaza ve dolayısıyla İstanbul'a giriș kapıları da aralanmıştı. Sadece 18 Mart'ta yaklaşık yedi saat süren ( Sabah 10:30'da düşman gemileri Boğaza girmiş ve ilk saldırı yaklaşık 11:15 gibi başlamıştır. Akşam 18:00 sularında ise düşman gemileri geri çekilmeye başlayacaktır.) saldırıda yalnızca İngiliz gemilerince yaklaşık 3.344 mermi atışı yapılmıştı.

Denizde hüsrana uğratılan Birleşik Filo'nun karada son darbeyi yemesi Türk tarafından büyük bir mücadelenin kazanımıydı. Bu kazanımın deniz başarısı hiç kuşkusuz Cevat Paşa'nın komutasında gerçekleşmiștir. İstanbul'u Çanakkale'den geçerek alacaklarını ve Osmanlı Devleti'nin kalbini ele geçirerek mevcut planlarını uygulamayı düşünen İtilaf güçleri 18 Mart 1915’te bunun asla kolay olamayacağını anlamıştır. Çanakkale, Nusret Mayın gemisiyle geçilemedi sözü eksik bir tanım olmasa 
gerek. 7 - 8 Mart gecesi Nusret Mayın gemisinin döktüğü 26 mayın Çanakkale'yi geçilmez kılmıştı. Dünyanın en güçlü donanması olarak duyurulmuş Birleşik Filo, hiç beklemedikleri bir kayıp yaşamıştır. Ayrıca bu yenilgi onlara itibar ve güven kaybını da yaşatmıștır. Türk askerinin başarısı dünya ve iç basında geniş yer kaplamış, Cevat Paşa ise pek çok takdir ve nişana layık görülmüştür.

Çanakkale Deniz savaşları, tüm teçhizat eksiklerine rağmen inanç ve azimle kazanılmış bir savaştır. Kendinden emin güçlü İtilaf donanmasının planlarını alt üst eden ve geri çekilmek zorunda bırakan bu savaş ile parçalanmakta olan Osmanlı Devleti büyük bir başarı elde etmiştir. Cevat Paşa, Boğaz'dan düşman donanmasını geçirmeyerek 18 Mart Kahramanı ve Çanakkale Deniz Savaşlarında İstanbul'u kurtaran kişi olarak takdir toplamış ve tarihe bu şekilde adını yazdırmıştır. 


\section{KAYNAKÇA}

\section{Tetkik Eser, Makaleler ve Tezler}

Albayrak, Mustafa, Atatürk ve Türkiye Cumhuriyetinin Tarihsel Gelişimi, Atatürk Araştırma Merkezi Yayınları, Ankara,1999

Baş, Nurdan, Orgeneral Cevat Çobanlı́nın Biyografisi, (Yayınlanmamış Yüksek Lisans Tezi), Ankara, 2013

Baycan, Nusret, “Orgeneral Cevat Çobanlı”, Atatürk Araștırma Merkezi Dergisi, Sayı 20, Cilt. VII, Ankara, 1991

Birinci Dünya Savaşında Çanakkale Cephesi, (Yayın Kurulu Başkanı Kamil Başoğlu), Cilt V. 1.Kitap, Genelkurmay Yayınları, Ankara,2012

Doğanay, Rahmi, “Çanakkale Zaferinin Türk ve Dünya Tarihi Açısından Önemi”, Atatürk Yolu Dergisi, Ankara Üniversitesi Türk İnkılap Tarihi Enstitüsü Yayınları, Ankara,1993

Duman, Murat, Cumhuriyetimizin Önsözü Çanakkale Savaşlar Hatıralar ve Kahramanlar, İstanbul, 2006

Erdemir, Lokman, “Çanakkale Boğazında İlk Bombardıman ve İstanbul”, İstanbul, 2015

Görgülü, İsmet, On Ylllık Harbin Kadrosu 1912-1922, Türk Tarih Kurumu Yayınları, Ankara, 1993

Görgülü, İsmet, “Çanakkale'de Almanların Niyeti”, Çanakkale Araştırmaları Türk Yıllı̆̆ı Dergisi, S.1, Çanakkale, 2003

Güven, Sinem, Hatırat Türü Eserlerde Çanakkale Muharebeleri, (Yayınlanmamış Yüksek Lisan Tezi), Ankara, 2007

Halaçoğlu, Ahmet, "Birinci Dünya Savaşında Türk Donanması ve Çanakkale Deniz Operasyonu”, Askeri Tarih Bülteni, Genelkurmay Yayınları, Ankara, 1988

İğdemir, Uluğ, Anafartalar Muharebatı’na Ait Tarihçe, Türk Tarih Kurumu Yayınları, Ankara, 1990

Kocatürk, Utkan, Doğumdan Ölümüne Kadar Kaynakçalı Atatürk Günlüğü, Atatürk Araştırma Merkezi Yayınları, Ankara, 2007

Kaşıyuğun,Ali, “ Osmanlı Devleti’nin Birinci Dünya Savaşına Girmeden Önceki İttifak Arayıșları”, History Studies Dergisi, 2009

Mustafa Kemal, Arıburnu Muharebeleri Raporu, (Yay. Hzr. Uluğ İğdemir), Türk Tarih Kurumu Yayınları, Ankara, 1990

Osmanlı Belgelerinde Çanakkale Muharebeleri 1, (Proje Yön. Yusuf Sarınay), Başbakanlık Devlet Arşivleri Yayınları, Ankara,2005

Özdemir, İslam, “18 Mart Özel Yazısı: Dardanos’a Şan Verenler” , www.geliboluyuanlamak. com, $(17 / 03 / 2011)$

Özkaya, Yücel, “ 1914-1918 Yılları Arasında Birinci Dünya Savaşı”, Milli Mücadele Tarihi, Cilt.1, Atatürk Araştırma Merkezi Yayınları, Ankara, 2005 
Öztürk, Hayri, “ Servet-i Fünün'da Çanakkale Zaferi”, TÜBAR Dergisi, XII. Güz,2002

Öztürk, Hüsamettin, “ Çanakkale'nin Mustafa Kemal'in Askeri Kariyerindeki Yeri”, 85. Yılında Çanakkale Savaşları Sempozyumu, (23-24 Mart 2000 Çanakkale) Sempozyum Bildirileri, 18 Mart Üniversitesi Çanakkale Savaşları Araştırma Merkezi, Çanakkale, 2000

Sarıkoyuncu, Ali; Sarıkoyuncu Değerli, Esra, “Avusturya Basınında Çanakkale Muharebeleri”, ATAM Dergisi Cilt. 25, Sayı.73, Ankara,2009

Selahaddin Adil Paşa, Çanakkale Cephesinden Mektuplar-Hatıralar, (Yay. Hzr. Muzaffer Albayrak), Yeditepe Yayınları, 1.Baskı, İstanbul,2007

Selçuk, Mustafa, Hedef Şehir İstanbul, Emre Yayınları, İstanbul, 2005

Semiz, Yaşar, "18 Mart Çanakkale Deniz Savaşı: Sebepleri,Gelişimi ve Sonuçları”, Türkiyat Araştırmaları Dergisi,S.14, Selçuk Üniversitesi, http://www.turkiyat.selcuk.edu.tr

Süslü, Azmi, “ Çanakkale Savaşları ve Önemi”, ATAM Dergisi, S.20, C.VII, Ankara, 1991

Şafak, Erdal,“Atını Dinyester'de Sulayan Komutan” www.sabah.com.tr, (2006/12/10)

Tarhan, Mukbile, "18 Mart Zaferi”, (sadeleștiren, Nesrin Tarkan), Milliyet Gazetesi, 18 Mart 1970

Taşkıran, Cemalettin, “18 Mart Çanakkale Deniz Savaşı”, ATAM Dergisi, Cilt.25, S.73,Ankara, 2009

Turan, Kemal, “95. Yıldönümünde Çanakkale Zaferi”, ATAM Dergisi, Cilt: 25, Ankara, 2009

Uçarol, Rıfat, Siyasi Tarih, Filiz Kitapevi, İstanbul 2000

Yetkin, Gıyas, "Yaratanların Ağzından 18 Mart 1915 Çanakkale Zaferi”, Türkiye Eski Muharipler Cemiyeti Yay. Ankara, 1966

Yuttakal, Ahmet, "18 Mart Kahramanı Cevat Paşa”, www.geliboluyuanlamak.com, (09/04/2009)

Yüksel, Ş. Orhan, “50 Yıl Önce Çanakkale Savaşını Kazandık”, Tarih Mecmuası, Cilt.1, Sayı2, İstanbul,1965

\section{Gazeteler ve Dergiler}

Tanin Gazetesi, 24 Mart 1915

Milliyet Gazetesi, 18 Mart 1970

Yedigün Dergisi, 1936,No:180

Tarih Mecmuası, Cilt 1, 1965

Tasvir-i Efkâr, 29 Ekim 1915

1453 Istanbul Kültür ve Sanat Dergisi,S.21, 2015

\section{Arşiv Belgeleri}

ATASE, BDH Koleksiyonu, Kls. 4669, Dos. H-1, Fih.1

ATASE, Kls. 4669, D.: H-3. Fih.1-53

BELLETEN, C.VII, Ankara,1943 
EK:1 24 Mart 1915’te Tanin Gazetesinde II. Kaizer Wilhem’ın, Enver Paşa'ya gönderdiği Cevat Paşa Hakkındaki Düşüncelerini İçeren Telgrafın Haber Metni
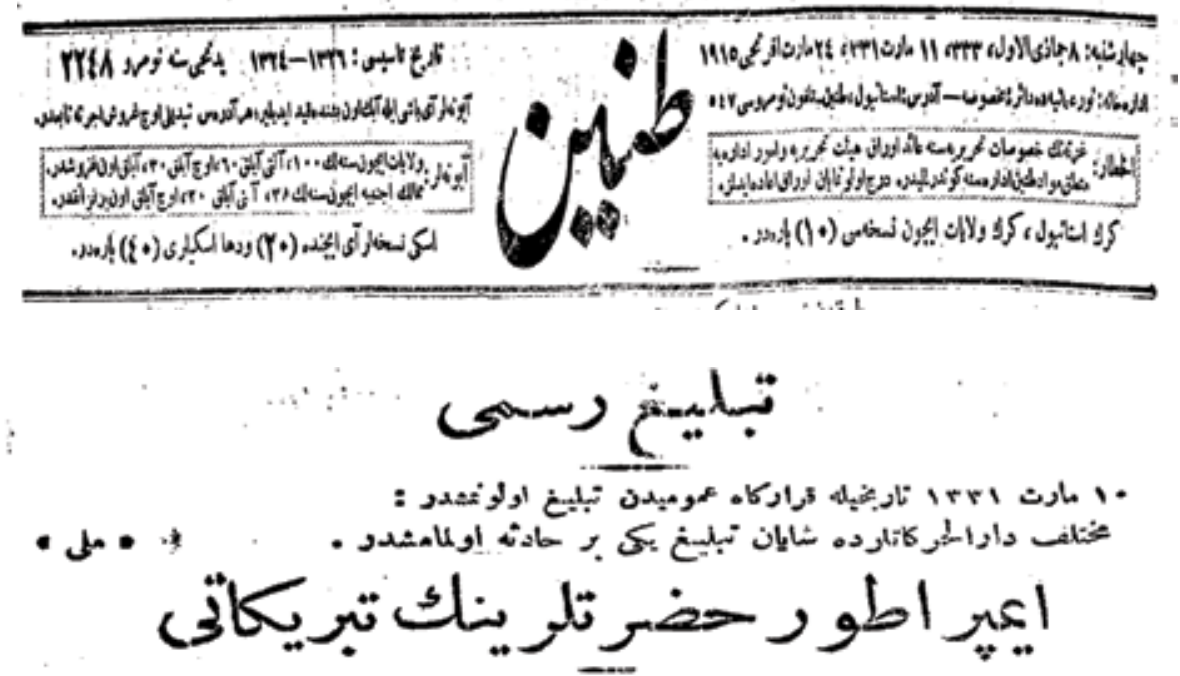

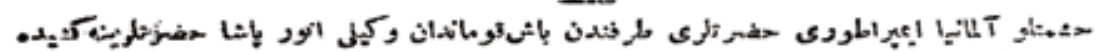

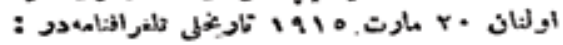

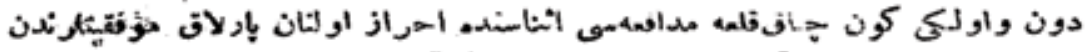

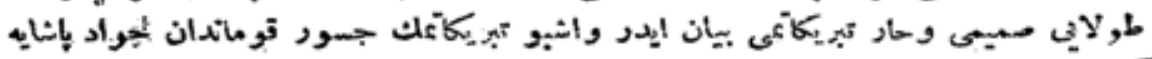

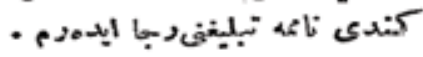

" .

Tebriğ-i Resmi

“Dün ve Evvelki gün Çanakkale müdafaası esnasında ihraz olunan parlak muvaffakiyetlerinden dolayı samimi hassı tebrikatımı beyan eder, iş bu tebrikatımızın cesur kumandanı Cevat Paşa'ya kendi namına tebriğini rica ederim. Cenab-ı Hak bundan böyle dahi silahlarımızı tevfikat-ı rabbaniyesine mazhar buyursun." 


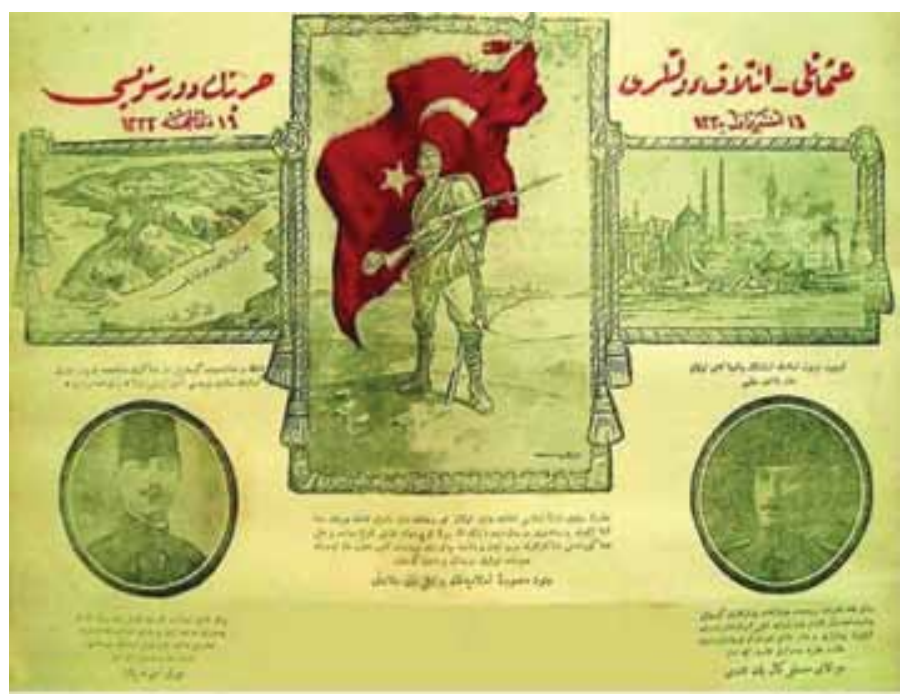

EK:2 29 Ekim 1915 Tasvir-i Efkâr Gazetesinin Baş Sayfasında Yer Alan Çanakkale Cephesindeki hem deniz hem de kara savaşlarında Mustafa Kemal Paşa ve Cevat Paşa'nın Fotoğraflarının Bulunduğu, Onların üstün başarılarının yer aldığı gazete haberi; haberde Cevat Paşa hakkında şu ifadeler kullanılmıştır: "Çanakkale'yi muhacemat- $\imath$ bahriyeye karşı pek büyük iktidar ve maharetle müdafaa eden ve mefahir-i milliyemize 5 Mart (18 Mart 1915) muzafferiyetini ilave eden Mevki-i Müstahkem Kumandan $\iota$ necabet-i fi triye ile mümtaz Mirliva Cevat Paşa"

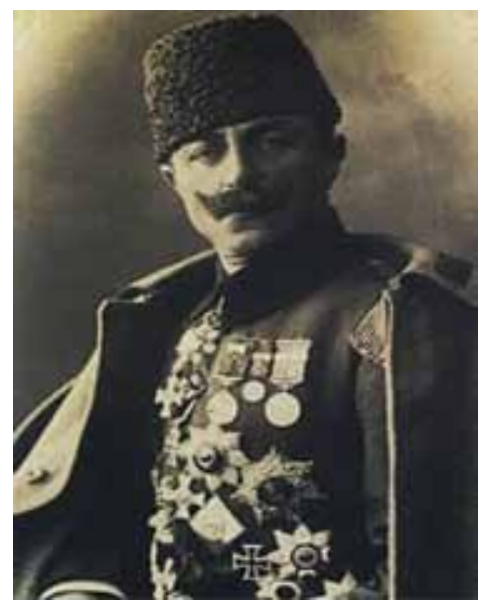

EK:3 Orgeneral Cevat ÇOBANLI'nın Portresi, www.geliboluyuanlamak.com, 17.03.2011 
Ek:4 Cevat Paşa'nın Çanakkale Deniz Savaşlarında göstermiş olduğu başarıya ilişkin kendisi hakkında sunulan belgelerdir. Belgeler, Nusret Baycan'ın “Orgeneral Cevat Çobanlı” makalesinden alınmıştır.

Belge:1

Doğu Ordusu Başkomutanlığı

Genel Karargâh

12.6.1917

15 nci Osmanlı Kolorduyu Hümâyunu Kumandanı Mirliva Cevat Paşa Hazretlerine

Gösterdiği cesaret ve göreve bağlılı̆̆ından dolayı 15 nci Türk Kolordusuna, emir ve komutasını üzerime aldığım harekât alanından ayrıldığı şu sırada, sonsuz teşekkür ve takdirlerimi bildiririm. Rusların sayıca çok üstün kuvvetlerle Narajowka, Zlota Lipa, Brzezany dolaylarında yaptıkları meydan muharebesinde, yiğit kolordu olağanüstü cesaretle direnmiş ve karşı taarruzlarla bozguna uğrayan düşmanı takip etmişti. Bundan sonra Mieczyszcow ve Dziki-Lany Çevrelerinde giriştikleri muharebelerde Ruslar aynı yenilgiye uğradi. Kolordunun daima uyanık bulunan tecrübeli askerleri kuvvetli mukabeleleriyle bu taarruzları da tam olarak püskürttüler Doğu Cephesi'nde, bu derece benzersiz olarak yaptığı muharebelerle savaş yeteneğini göstermiş ve ispat etmiş bulunan bu kolordudan ayrllışıma üzgünüm. Cesur kolordunun bütün subay ve erlerine, bundan sonra da, yeni bulunacakları muharebe alanlarında başarılara ulaşmalarını dilerim.

Bavyera Prensi Leopolt Mareşal Doğu Ordusu Başkomutan

Belge:2 Avusturya-Macaristan Böhm Ermolli Ordular Grubu Komutanlı̆̆ Sayı: 3589/27 Haziran 1917

\section{5 nci Osmanlı Kolordusu Kumandanı Cevat Paşa Hazretlerine}

15 nci Türk Kolordusu savaş bölgemden ayrllyor. Kolorduyu çok üstün sevk ve idare eden komutanına şu vesile ile özel teşekkürlerimi bildiririm. Parlak, benzersiz icratıyla, özellikle silâh arkadaşlı̆̆ına bă̆lılı̆̆ı ile yüzyıllardan beri denenmiş bulunan Türk askeri, Ordular Grubu tarihine yazdiğ l pek şerefli sahifelerle unutulmaz bir yer tutacaktır. Kazandıkları sonsuz ve derin güven ve övgülerin bütün subaylara ve erlere duyurulmasını yüksek şahsınızdan rica ederim.Iyi dileklerim kolorduyu yeni yolu üzerinde de izleyecektir. Bundan sonra da daima yolu açık olsun ve şanlı sancağı yeni zaferler, seçkin basanlarla dalgalansin.

Böhm Ermolli Ordular Grubu Komutanı 
Ek:5. Bu belge, Almanya Devleti tarafından Bahr-ı Sefid Boğazı Kumandanı Cevat Paşa'ya ikinci rütbeden Croix de Fer nişanının verilmesiyle ilgilidir. Kaynak, Osmanlı Belgelerinde Çanakkale Muharebeleri 1, Belge:54

Bâb-ı Âlî

Hariciye Nezâreti

Sicill-i Ahvâl Müdüriyeti

Aded: 63751/70

Cevad Paşa hazretlerine verilen

Alman nişânı hakkında

Huzûr-ı Sâmî̀-i Cenâb-ı Sadâret-penâhîye

Ma'rûz-l çâker-i kemîneleridir

Boğaz’n emr-i müdafaasında istihsâl olunan muvaffakiyet-i askeriyeden dolayı Bahr-ı Sefîd Boğazı Kumandanı Cevad Paşa hazretlerine Almanya Devleti tarafindan i'tâ kılınan ikinci rütbeden Croix de Fer nişânının müşârunileyh tarafindan kabul ve ta'likki istîzân buyurulmak üzere tanzim olunan irâde-i seniyye lâyihası leffen pîşgâh-ı sâmî-i Sadâret-penâhîlerine takdim kılınmıısdır. Ol bâbda emr u fermân hazret-i veliyyüll-emrindir.

Fî 28 Cumâdelûlâ sene [1]333 ve fî 31 Mart sene [1]331 / [13 Nisan 1915]

Hariciye Nâzırı

Mehmed Said 


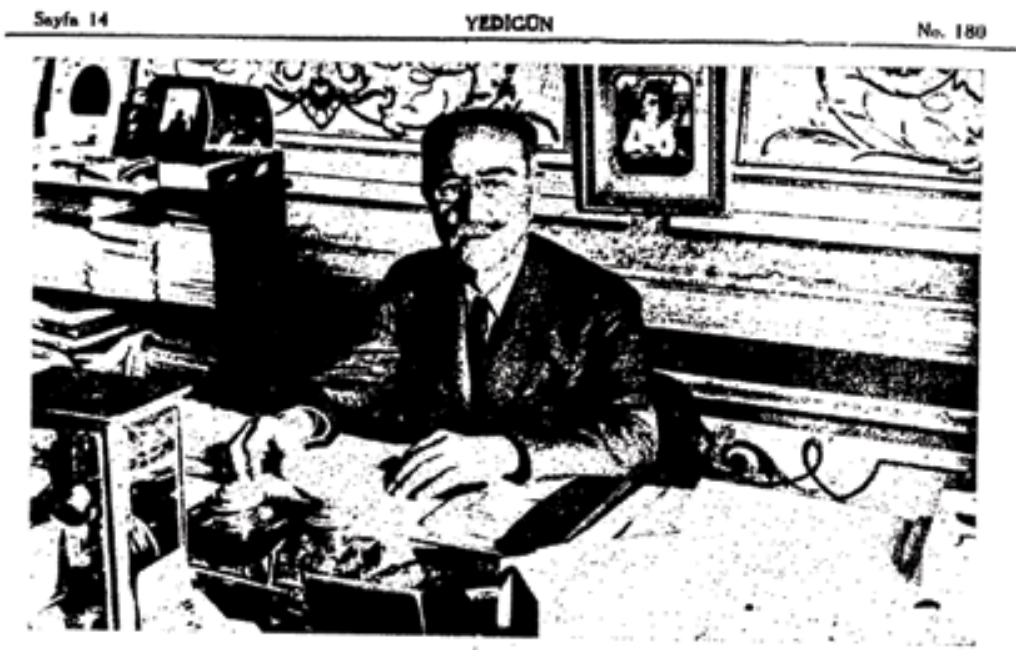

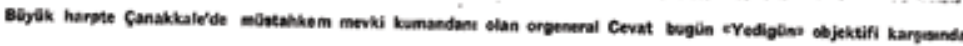

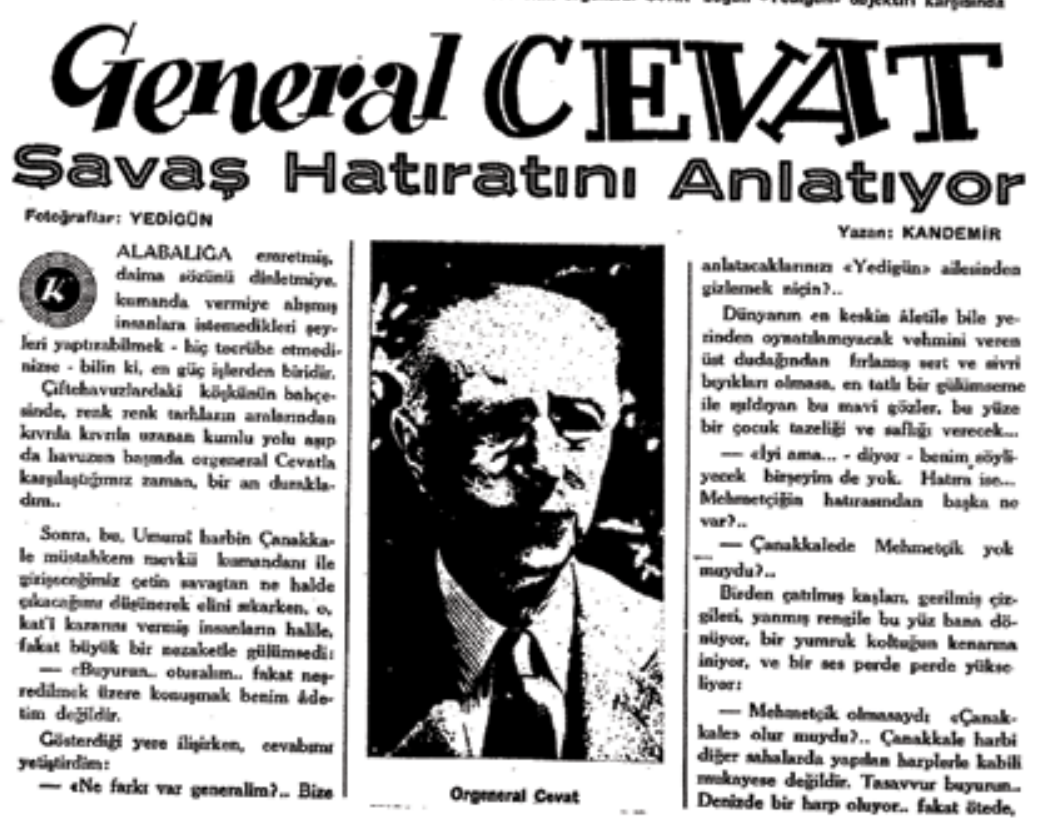

EK:6 Cevat Paşa'nın 1936 Yılında Yayınlanan Yedigün Dergisinde Yer Alan Röportajın İlk Sayfası 